University of South Carolina

Scholar Commons

1999

\title{
Mathematical Modeling of the Lithium Deposition Overcharge Reaction in Lithium-Ion Batteries Using Carbon-Based Negative Electrodes
}

\author{
Pankaj Arora \\ University of South Carolina - Columbia \\ Marc Doyle \\ Ralph E. White \\ University of South Carolina - Columbia, white@cec.sc.edu
}

Follow this and additional works at: https://scholarcommons.sc.edu/eche_facpub

Part of the Chemical Engineering Commons

\section{Publication Info}

Published in Journal of the Electrochemical Society, Volume 146, Issue 10, 1999, pages 3543-3553.

(c) The Electrochemical Society, Inc. 1999. All rights reserved. Except as provided under U.S. copyright law, this work may not be reproduced, resold, distributed, or modified without the express permission of The Electrochemical Society (ECS). The archival version of this work was published in Arora, P., Doyle, M., \& White, R.E. (1999). Mathematical Modeling of the Lithium Deposition Overcharge Reaction in Lithium-Ion Batteries using Carbon-Based Negative Electrodes. Journal of the Electrochemical Society, 146(10) 3543-3553.

Publisher's Version: http://dx.doi.org/10.1149/1.1392512

This Article is brought to you by the Chemical Engineering, Department of at Scholar Commons. It has been accepted for inclusion in Faculty Publications by an authorized administrator of Scholar Commons. For more information, please contact digres@mailbox.sc.edu. 


\title{
Mathematical Modeling of the Lithium Deposition Overcharge Reaction in Lithium-Ion Batteries Using Carbon-Based Negative Electrodes
}

\author{
Pankaj Arora, ${ }^{\mathrm{a}, *}$ Marc Doyle, ${ }^{\mathrm{b}, * *}$ and Ralph E. White ${ }^{\mathrm{a}, * *}$ \\ ${ }^{a}$ Center for Electrochemical Engineering, Department of Chemical Engineering, University of South Carolina, Columbia, South \\ Carolina 29208, USA \\ ${ }^{b}$ DuPont Central Research and Development, Experimental Station, Wilmington, Delaware 19880-0262, USA
}

\begin{abstract}
The processes that lead to capacity fading affect severely the cycle life and rate behavior of lithium-ion cells. One such process is the overcharge of the negative electrode causing lithium deposition, which can lead to capacity losses including a loss of active lithium and electrolyte and represents a potential safety hazard. A mathematical model is presented to predict lithium deposition on the negative electrode under a variety of operating conditions. The $\mathrm{Li}_{x} \mathrm{C}_{6} \mid 1 \mathrm{M} \mathrm{LiPF}_{6}, 2: 1$ ethylene carbonate/dimethyl carbonate, poly(vinylidene fluoride-hexalfuoropropylene) $\mid \mathrm{LiMn}_{2} \mathrm{O}_{4}$ cell is simulated to investigate the influence of lithium deposition on the charging behavior of intercalation electrodes. The model is used to study the effect of key design parameters (particle size, electrode thickness, and mass ratio) on the lithium deposition overcharge reaction. The model predictions are compared for coke and graphite-based negative electrodes. The cycling behavior of these cells is simulated before and after overcharge to understand the effect of overcharge on extended cycling. These results can be used to establish operational and design limits within which safety hazards and capacity fade problems, inherent in these cells, can be minimized.

(C) 1999 The Electrochemical Society. S0013-4651(99)01-088-5. All rights reserved.
\end{abstract}

Manuscript submitted January 25, 1999; revised manuscript received May 10, 1999.

Two major issues facing lithium-ion battery technology are safety and capacity fade during cycling. A significant amount of work has been done to improve the cycle life and to reduce the safety problems associated with these cells. This includes newer and better electrode materials, lower-temperature shutdown separators, nonflammable or self-extinguishing electrolytes, and improved cell designs. The performance of these cells is based on the complex chemical and electrochemical reactions occurring during charge, discharge, and storage, many of which are irreversible and lead to changes in the performance of the cells during extended cycling. A detailed discussion of lithium-ion battery mathematical models and side reactions can be found elsewhere. ${ }^{1}$ These complex phenomena can be understood in a more detailed manner through mathematical modeling of the full-cell sandwich.

Several mathematical models of lithium-ion cells have been published. ${ }^{2-6}$ None of these models has the capability to predict capacity fade observed in these cells. Doyle et al. ${ }^{4}$ modified their dual lithiumion model to include film resistances on both electrodes and made direct comparisons with experimental cell data for the $\mathrm{Li}_{x} \mathrm{C}_{6} \mid \mathrm{LiPF}_{6}$, ethylene carbonate/dimethyl carbonate (EC/DMC), poly(vinylidene fluoride-hexafluoropropylene) $\mid \mathrm{Li}_{y} \mathrm{Mn}_{2} \mathrm{O}_{4}$ system. The discharge performance of the cells was described satisfactorily by including either a film resistance on the electrode particles or by contact resistances between the cell layers or current collector interfaces. ${ }^{4,5}$

Recently Darling and Newman made the first attempt to model side reactions in lithium batteries by incorporating an electrolyte ( $1 \mathrm{M} \mathrm{LiClO}_{4}$ in PC) oxidation side reaction into a lithium-ion battery model. ${ }^{6}$ Even though a simplified treatment of the oxidation reaction was used, these authors were able to make several interesting conclusions about self-discharge processes in these cells and their impact on positive electrode state-of-charge.

Present battery models, except the one by Darling and Newman, consider the "ideal behavior" of the systems, neglecting the phenomena that led to losses in capacity during repeated charge-discharge cycles. Fundamental models of capacity fade phenomena are less common because their processes are not as well understood. Also, models of failure modes in batteries are not usually applicable to a wide range of systems. However, the importance of these phenomena in the safe and efficient operation of high-energy lithium-ion batteries requires that they be incorporated into future battery models.

\footnotetext{
* Electrochemical Society Student Member.

** Electrochemical Society Active Member.
}

The goal of this work is to predict the conditions for the lithium deposition overcharge reaction on the negative electrode (graphite and coke) and to investigate the effect of various operating conditions, cell designs and charging protocols on the lithium deposition side reaction.

\section{Model Development}

Lithium deposition is expected to occur in lithium-ion cells due to either a higher than desired initial mass ratio, lower than expected lithium losses during the formation period, adverse charging conditions, or accidental overcharging (malfunctioning charger, malfunctioning safety circuit, or electrical misuse/abuse of the battery pack). The freshly deposited lithium covers the active surface area of the negative electrode leading to a loss of cyclable lithium and consumption of electrolyte because of the highly reactive nature of metallic lithium. This may occur at high charge rates even for cells with a conservative mass ratio because of the polarization at the negative electrode under charging conditions. ${ }^{4}$

However, a common circumstance leading to lithium deposition may be poorly balanced cells having too much positive electrode mass initially. Note that there is no industry standard for electrode mass ratio or anode excess for lithium-ion cells. The mass ratio $(\gamma)$ of a lithium-ion cell is defined as

$$
\gamma_{\text {actual }}=\frac{m_{+}}{m_{-}}=\frac{\delta_{+} \epsilon_{+} \rho_{+}}{\delta_{-} \epsilon_{-} \rho_{-}} \quad \gamma_{\text {theoretical }}=\frac{\Delta x \mathrm{C}_{-}}{\Delta y \mathrm{C}_{+}}
$$

where $\gamma_{\text {actual }}$ is the actual mass ratio and $\gamma_{\text {theoretical }}$ is the theoretical mass ratio. The intercalation-deintercalation reaction on the negative electrode (graphite or coke) may be written as

$$
\mathrm{C}_{6}+x \mathrm{Li}^{+}+x \mathrm{e}^{-} \underset{\text { discharge }}{\stackrel{\text { charge }}{\rightleftarrows}} \mathrm{Li}_{x} \mathrm{C}_{6}
$$

and the primary side reaction involved in the overcharge process is

$$
\mathrm{Li}^{+}+\mathrm{e}^{-} \rightarrow \mathrm{Li}(\mathrm{s})
$$

The lithium metal is expected to form first near the electrode-separator boundary where the surface overpotential is greatest. Lithium metal deposited on the negative electrode reacts quickly with solvent or salt molecules in the vicinity giving $\mathrm{Li}_{2} \mathrm{CO}_{3}, \mathrm{LiF}$, or other insoluble products as shown in Fig. 1.7,8 A thin film of products (formed above) protects the solid lithium from reacting with the electrolyte. This lithium, if in electronic contact with the negative electrode, can 


\section{Negative Electrode (Coke or Graphite)}

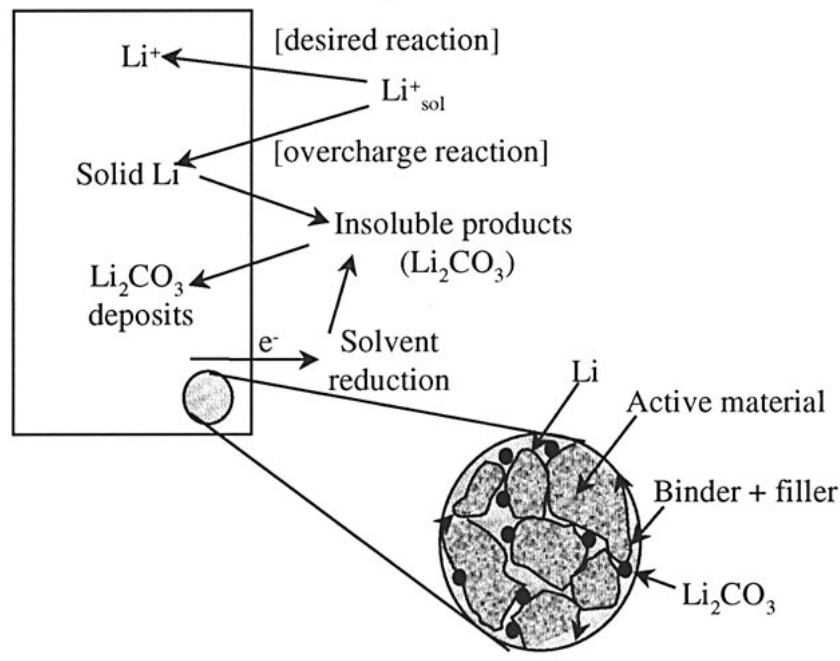

Negative Electrode: $\quad \mathrm{C}_{6}$

$\mathrm{Li}_{\mathrm{x}} \mathrm{C}_{6}$

$\mathrm{Li}_{\mathrm{x}} \mathrm{C}_{6}+\mathrm{Li}$

Discharged

Charged

Overcharged

Figure 1. Reactions occurring on the negative electrode during charge and overcharge.

still dissolve during discharge. The film formed over the solid lithium is a direct loss of both active lithium and electrolyte. The products formed may block the pores, leading to a loss of rate capability as well as capacity losses. Formation of lithium metal is also a safety hazard due to its extreme reactivity with liquid solvents.

A schematic of a lithium-ion cell is shown in Fig. 2. It consists of a composite negative electrode (active material + filler + binder), separator and a composite positive electrode. The negative and positive active materials simulated in this work are graphite (MCMB 2528) and $\mathrm{LiMn}_{2} \mathrm{O}_{4}$, respectively. Other details and data for the $\mathrm{Li}_{x} \mathrm{C}_{6}|1 \mathrm{M} \mathrm{LiPF}, \mathrm{EC} / \mathrm{DMC}, \mathrm{p}(\mathrm{VdF}-\mathrm{HFP})| \mathrm{Li}_{y} \mathrm{Mn}_{2} \mathrm{O}_{4}$ system are given elsewhere. ${ }^{4}$ Lithium metal deposition may be more of a concern with graphitic carbon electrodes than with coke electrodes due to the lower average open-circuit potential of the former. For this reason, mass ratios in cells using graphite are usually chosen to be much smaller than the optimum in order to provide a buffer against lithium deposition, with the consequence that the full $372 \mathrm{mAh} / \mathrm{g}$ capacity of the graphite is not utilized. The model predictions for

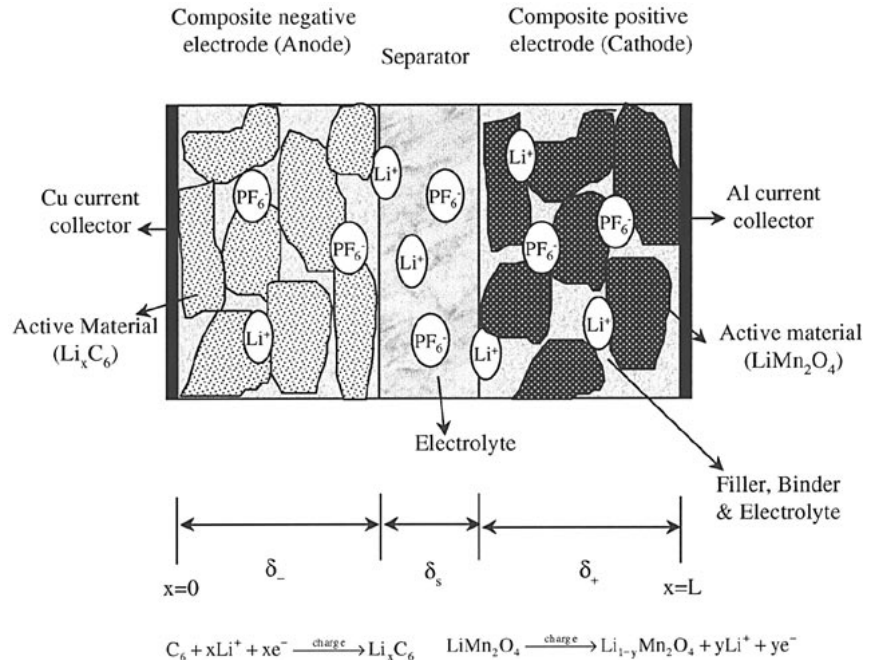

Figure 2. Schematic of lithium-ion cell during charge. graphite-based negative electrodes are compared with coke-based negative electrodes.

The main side reaction in the negative electrode during overcharge is given by Eq. 3, which can be written in general notation as ${ }^{9}$

$$
\sum_{i} s_{\mathrm{i}} M_{\mathrm{i}}^{\mathrm{Z}_{\mathrm{i}}} \rightarrow n \mathrm{e}^{-}
$$

The rate of the lithium deposition reaction is charge-transfer-kinetic controlled and can be expressed by a Butler-Volmer expression as follows

$$
i_{\mathrm{k}}=i_{\mathrm{o}, \mathrm{k}}\left[\exp \left(\frac{\alpha_{\mathrm{a}, \mathrm{k}} F}{R T} \eta_{\mathrm{s}, \mathrm{k}}\right)-\exp \left(-\frac{\alpha_{\mathrm{c}, \mathrm{k}} F}{R T} \eta_{\mathrm{s}, \mathrm{k}}\right)\right]
$$

A number of different approximations can be made to simplify the computational process while including the lithium metal deposition side reaction. Either a Tafel or linear approximation to the Butler-Volmer rate expression can be used depending on the reaction conditions and simplifying assumptions. The cathodic Tafel expression can be used to describe the rate expression if either the deposition reaction is considered to be irreversible or if the amount of lithium deposited is very small and reacts quickly with the solvent. In that case, the rate expression will be

$$
i_{\mathrm{k}}=-i_{\mathrm{o}, \mathrm{k}} \exp \left(-\frac{\alpha_{\mathrm{c}, \mathrm{k}} F}{R T} \eta_{\mathrm{s}, \mathrm{k}}\right)
$$

The lithium deposition reaction is a facile process under many conditions; the surface overpotentials may be sufficiently low that the reaction can be expressed adequately using the linear approximation

$$
i_{\mathrm{k}}=i_{\mathrm{o}, \mathrm{k}} \frac{\left(\alpha_{\mathrm{a}, \mathrm{k}}+\alpha_{\mathrm{c}, \mathrm{k}}\right) F}{R T} \eta_{\mathrm{s}, \mathrm{k}}
$$

In this work, we have assumed that the lithium deposition reaction is semireversible, i.e., at least part of the deposited lithium can dissolve during discharge. Some amount of the lithium may react with the electrolyte to form insoluble products such as $\mathrm{Li}_{2} \mathrm{CO}_{3}$, etc. A cathodic Tafel rate expression is also incorporated in the model and model predictions will be compared for both cases (ButlerVolmer and Tafel rate expression). In the above expressions (Eq. 5, 6 , and 7), $i_{\mathrm{o}, \mathrm{k}}$ is the exchange-current density and $\eta_{\mathrm{s}, \mathrm{k}}$ is the local value of surface overpotential defined by

$$
\eta_{\mathrm{s}, \mathrm{k}}=\phi_{1}-\phi_{2}-U_{\mathrm{k}}-F j_{\mathrm{n}, \mathrm{k}} R_{\mathrm{film}}
$$

where $U_{\mathrm{k}}$ is the open-circuit potential. The potential variables $\phi_{1}$ and $\phi_{2}$ represent the potentials in the solid and solution phases, respectively, and $i_{\mathrm{o}, \mathrm{k}}, \alpha_{\mathrm{ak}}$, and $\alpha_{\mathrm{ck}}$ are the kinetic parameters. Here

$$
\alpha_{\mathrm{s}, \mathrm{k}}+\alpha_{\mathrm{c}, \mathrm{k}}=1
$$

Based on the above discussion and assumptions, application of Eq. 5 to reactions 2 and 3 results in the following kinetic expressions

$$
j_{\mathrm{n}, 1}=\frac{i_{0,1}}{F}\left[\begin{array}{c}
{\left[\exp \left(\frac{\alpha_{\mathrm{a}, 1} F}{R T}\left[\phi_{1}-\phi_{2}-U_{1}\left(c_{s}\right)-F j_{\mathrm{n}, 1} R_{\mathrm{film}}\right]\right)\right]} \\
\left.-\left[\exp \left(-\frac{\alpha_{\mathrm{c}, 1} F}{R T}\left[\phi_{1}-\phi_{2}-U_{1}\left(c_{s}\right)-F j_{\mathrm{n}, 1} R_{\mathrm{film}}\right]\right)\right]\right]
\end{array}\right]
$$

and

$$
j_{\mathrm{n}, 2}=\frac{i_{0,2}}{F}\left[\begin{array}{c}
{\left[\exp \left(\frac{\alpha_{\mathrm{a}, 2} F}{R T}\left[\phi_{1}-\phi_{2}-U_{2}-F j_{\mathrm{n}, 2} R_{\mathrm{film}}\right]\right)\right]} \\
\left.-\left[\exp \left(-\frac{\alpha_{\mathrm{c}, 2} F}{R T}\left[\phi_{1}-\phi_{2}-U_{2}-F j_{\mathrm{n}, 2} R_{\mathrm{film}}\right]\right)\right]\right]
\end{array}\right]
$$

where $j_{\mathrm{n}, 1}$ and $j_{\mathrm{n}, 2}$ correspond to the rates of the lithium intercalation and lithium deposition reactions. The normal component of the cur- 
rent density is related to the pore wall flux by $i_{\mathrm{n}}=F j_{\mathrm{n}}$. The open-circuit potential $U_{2}$ is equal to zero because we are measuring the potential with respect to a lithium metal reference electrode in solution at the same local concentration. $R_{\text {film }}\left(\Omega \mathrm{cm}^{2}\right)$ is a resistance caused by the film formed over the electrode surface. The resistance of the film is treated by modifying the Butler-Volmer kinetic expression for the insertion reaction and the lithium deposition reaction as shown in Eq. 10 and 11. The exchange-current densities for the insertion reaction $\left(i_{0,1}\right)$ and lithium deposition reaction $\left(i_{0,2}\right)$ have the form

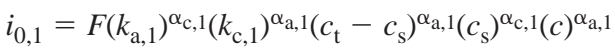

$$
\begin{aligned}
& i_{0,2}=F\left(k_{\mathrm{a}, 2}\right)^{\alpha_{\mathrm{c}, 2}}\left(k_{\mathrm{c}, 2}\right)^{\alpha_{\mathrm{a}, 2}(c)^{\alpha \mathrm{a}, 2}}
\end{aligned}
$$

The open-circuit potential $U_{1}$ is a function of the amount of lithium inserted and can be described by Eq. 14 for mesocarbon (MCMB) $2528^{4}$

$$
\begin{array}{r}
U_{1}=0.7222+0.13868 x+0.028952\left(x^{0.5}\right)-0.017189\left(\frac{1}{x}\right) \\
+0.0019144\left(\frac{1}{x^{1.5}}\right)+0.28082 \exp [15(0.06-x)] \\
\quad-0.79844 \exp [0.44649(x-0.92)]
\end{array}
$$

where $x$ is $c_{\mathrm{s}} / c_{\mathrm{t}}$. The kinetic and thermodynamic parameters used to simulate the electrochemical reactions on the negative electrode are summarized in Table I. According to Jasinski et al. ${ }^{10} \mathrm{Li} / \mathrm{Li}^{+}$has a high exchange current density in $1 \mathrm{M} \mathrm{LiClO}_{4}-\mathrm{PC}$, at least on the order of 2 to $5 \mathrm{~mA} / \mathrm{cm}^{2}$ for a smooth surface and a cathodic transfer coefficient ranging from 0.66 to 0.72 . The exchange current density for lithium deposition as reported by Verbrugge is $31.6 \mathrm{~mA} / \mathrm{cm}^{2}$ and the cathodic transfer coefficient is $0.67 .{ }^{11,12}$ In this work, the value of exchange current density is varied from 0.1 to $3 \mathrm{~mA} / \mathrm{cm}^{2}$ to examine its effect on overcharge.

The pore-wall flux $j_{\mathrm{n}, \mathrm{k}}$ is defined as the reaction rate per unit volume of the porous electrode and is equal to the divergence of the current density in solution

$$
\frac{1}{F} \nabla i_{2}=\sum_{k} a j_{\mathrm{n}, \mathrm{k}}
$$

The pore-wall flux across the interface is related to the flux of lithium ions into the solid phase by the boundary condition

$$
j_{\mathrm{n}, 1}=-D_{\mathrm{s}} \frac{\partial c_{\mathrm{s}}}{\partial r} \text { at } r=R_{\mathrm{s}}
$$

A material balance on solid lithium can be expressed as

$$
\frac{\partial c_{\mathrm{i}}}{\partial t}=-\nabla N_{\mathrm{i}}+R_{\mathrm{i}}
$$

where $R_{\mathrm{i}}$ is the production rate of species i per unit volume of the electrode due to the electrochemical reaction

Table I. Kinetic and thermodynamic parameters.

\begin{tabular}{lcl} 
Parameters & $\begin{array}{c}\text { Intercalation reaction } \\
\text { (Eq. 1) Value }\end{array}$ & $\begin{array}{c}\text { Deposition reaction } \\
\text { (Eq. 2) Value }\end{array}$ \\
\hline$i_{\mathrm{o}}\left(\mathrm{mA} / \mathrm{cm}^{2}\right)$ & $0.21^{\mathrm{a}}$ & $1.0^{10}$ \\
$\alpha_{\mathrm{a}}$ & $0.5^{\mathrm{b}}$ & 0.3 \\
$\alpha_{\mathrm{c}}$ & $0.5^{\mathrm{b}}$ & $0.7^{10,11}$ \\
$n$ & 1 & 1 \\
$U(v s . \mathrm{Li} / \mathrm{Li}+)$ & See Eq. $14^{5}$ & 0.0 \\
& \\
${ }^{\mathrm{a}}$ Calculated at initial conditions. \\
b Assumed.
\end{tabular}

$$
R_{\mathrm{i}}=-\frac{s_{\mathrm{i}, \mathrm{k}} a}{n_{\mathrm{k}} F} i_{\mathrm{n}, \mathrm{k}}
$$

For solids such as metallic lithium, the flux will be zero to a very good approximation. Thus the mass balance on the solid lithium reduces to

$$
\frac{\partial c_{\mathrm{Li}}}{\partial t}=-a \frac{i_{\mathrm{n}, 2}}{F}
$$

where $c_{\mathrm{Li}}$ is the moles of lithium metal per volume of electrode, and $a$ is the surface area to volume ratio as defined below for spherical carbon particles

$$
a=\frac{3\left(1-\epsilon_{1}-\epsilon_{\mathrm{p}}-\epsilon_{\mathrm{f}}\right)}{R_{\mathrm{S}}}
$$

By assuming that the negative-electrode particles are spherical in nature, the rate of the side reaction can be related to the growth of a film on the surface of the electrode particles according to

$$
\frac{\partial \delta_{\text {film }}}{\partial t}=-\frac{i_{\mathrm{n}, 2} M}{\rho F}
$$

where $\delta_{\text {film }}$ is the film thickness composed of solid lithium and other products and $M$ and $\rho$ are the molecular weight and density of lithium and products. The resistance $\left[R_{\text {products }}(t)\right]$ of the film formed by lithium and other products $\left(\mathrm{Li}_{2} \mathrm{CO}_{3}\right.$ is used as an example here) is given by

$$
R_{\text {products }}(t)=z_{\mathrm{Li}}\left(\frac{\delta_{\text {film }}}{\kappa_{\mathrm{Li}}}\right)+z_{\mathrm{Li}_{2} \mathrm{CO}_{3}}\left(\frac{\delta_{\text {film }}}{\kappa_{\mathrm{Li}_{2} \mathrm{CO}_{3}}}\right)
$$

where $z_{\mathrm{Li}}$ and $z_{\mathrm{Li}_{2} \mathrm{CO}_{3}}$ are the volume fractions of lithium and $\mathrm{Li}_{2} \mathrm{CO}_{3}$ present in the film. The film resistance in Eq. 8 is given by

$$
R_{\text {film }}=R_{\mathrm{SEI}}+R_{\text {products }}(t)
$$

for the negative electrode, where $R_{\mathrm{SEI}}$ corresponds to the resistance offered by the solid electrolyte interface (SEI) layer formed on the negative electrode active material during the formation period.

Recently Peled et al. proposed a complex two-layer multicomponent structure for the SEI layer formed on lithium and lithiated carbon electrodes. ${ }^{13}$ According to these authors, the inner layer (closer to the negative electrode) is rich in $\mathrm{Li}_{2} \mathrm{O}$ and $\mathrm{LiF}$ and low in $\mathrm{Li}_{2} \mathrm{CO}_{3}$, whereas the outer layer consists of $13 \% \mathrm{Li}_{2} \mathrm{CO}_{3}$ and other semicarbonates, $10 \% \mathrm{LiF}$, and the remainder polyolefins. In order to simplify the present mathematical model, the composition of the film formed during overcharge is assumed to consist of only $\mathrm{Li}$ and $\mathrm{Li}_{2} \mathrm{CO}_{3}$ in a single layer.

The mathematical model requires a number of physical properties. The design adjustable parameters and other parameters for the electrodes are given in Tables I, II, and III. The mathematical equations describing the electrochemical reactions, mass transport, and other physical processes within the cell are discussed in detail in Ref. 2 and 3. This nonlinear system of six independent governing equations and six dependent variables $\left(c, \phi_{2}, c_{\mathrm{s}}, i_{2}, j_{\mathrm{n}}, \phi_{1}\right)$ is solved using Newman's BAND subroutine.

Table II. Parameters for the electrodes.

\begin{tabular}{lcc} 
Parameter & $\mathrm{Li}_{x} \mathrm{C}_{6}$ & $\mathrm{Li}_{y} \mathrm{Mn}_{2} \mathrm{O}_{4}$ \\
\hline$D_{\mathrm{s}}\left(\mathrm{cm}^{2} / \mathrm{s}\right)$ & $2.0 \times 10^{-10}$ & $1.0 \times 10^{-9}$ \\
$\sigma_{\mathrm{o}}(\mathrm{S} / \mathrm{cm})$ & 1.0 & 0.038 \\
$i_{\mathrm{o}}\left(\mathrm{mA} / \mathrm{cm}^{2}\right)$ & 0.21 & 0.13 \\
$c_{\mathrm{t}}\left(\mathrm{mol} / \mathrm{dm}^{3}\right)$ & 30.54 & 22.86 \\
$\rho\left(\mathrm{g} / \mathrm{cm}^{3}\right)$ & 2.20 & 4.14
\end{tabular}


Table III. Design-adjustable parameters.

\begin{tabular}{lcc} 
Parameter & $\mathrm{Li}_{x} \mathrm{C}_{6}$ & $\mathrm{Li}_{y} \mathrm{Mn}_{2} \mathrm{O}_{4}$ \\
\hline$\delta(\mu \mathrm{m})$ & $99\left(19 \% \mathrm{ECE}^{\mathrm{a}}\right)$ & 179.3 \\
& $85\left(5 \% \mathrm{ECE}^{\mathrm{a}}\right)$ & \\
$R_{\mathrm{s}}(\mu \mathrm{m})$ & $80\left(0 \% \mathrm{ECE}^{\mathrm{a}}\right)$ & 8.5 \\
$c_{\mathrm{s}}^{\mathrm{o}}\left(\mathrm{mol} / \mathrm{dm}^{3}\right)$ & 12.5 & 3.92 \\
$\epsilon_{1}$ & 21.5 & 0.416 \\
$\delta_{\mathrm{cc}}(\mu \mathrm{m})$ & 0.360 & 16.0 \\
$T\left({ }^{\circ} \mathrm{C}\right)$ & 13.6 & \\
$c^{\mathrm{o}}\left(\mathrm{mol} / \mathrm{dm}^{3}\right)$ & 21.0 & \\
$\delta_{\mathrm{s}}(\mu \mathrm{m})$ & 1.00 & \\
$\epsilon_{\mathrm{ls}}$ & 76.2 & \\
$\epsilon_{\mathrm{ps}}$ & 0.593 & \\
$\epsilon_{\mathrm{SiO}}$ & 0.266 & \\
$\rho_{\mathrm{l}}\left(\mathrm{g} / \mathrm{cm}^{3}\right)$ & 0.141 & \\
$\rho_{\mathrm{p}}\left(\mathrm{g} / \mathrm{cm}^{3}\right)$ & 1.320 & \\
${ }^{\mathrm{a}}$ Excess carbon electrode. & 1.750 & \\
\end{tabular}

\section{Results and Discussion}

Lithium deposition is observed on carbon-based negative electrodes when lithium-ion cells are overcharged. To minimize the lithium deposition reaction most lithium-ion cells are manufactured with excess negative electrode (excess capacity). That is, if a lithium-ion cell consists of a positive electrode and negative electrode of equal reversible cyclable capacity, then at the end of charge (or at the beginning of overcharge) most of the applied current would go to the lithium deposition side reaction on the negative electrode. However, if excess negative electrode is present, then at the end of charge the negative electrode will still be undergoing the normal charging process (lithium intercalation). The lithium lost during lithium deposition may lead to changes in the capacity balance (Eq. 1).

For optimum performance, the ratio of the lithium-ion capacities of the two host materials should be balanced. The actual mass ratio calculated for the cell [mesocarbon microbead (MCMB) 2528/ $\mathrm{LiMn}_{2} \mathrm{O}_{4}$ ] modeled in this study is 2.47 . The theoretical mass ratio calculated on the basis of the theoretical capacity of the positive (148 $\mathrm{mAh} / \mathrm{g})$ and negative electrodes $(372 \mathrm{mAh} / \mathrm{g})$ is 3.03 when using $\Delta x=1.0$ and $\Delta y=0.83$. This leads to the conclusion that an excess of $18.6 \%$ capacity exists in the negative electrode. Considering also the irreversible capacity on the negative electrode (which can be 8 $12 \%$ for MCMB type graphite), it is apparent that a wide safety margin exists to prevent accidental lithium deposition on the graphite during charging. In commercial cells where other safety features would exist, cells might be designed differently to provide even higher energy densities by using a larger mass ratio closer to the theoretical value. On changing the thickness of the negative electrode to 80 and $85 \mu \mathrm{m}$, the excess capacity in the cell reduces to 0 and $5 \%$, respectively. The excess capacity in this work is defined as

$$
\text { Excess capacity }(\%)=\left(\frac{\gamma_{\text {theoretical }}-\gamma_{\text {actual }}}{\gamma_{\text {theoretical }}}\right) 100 \%
$$

Figure 3 shows the simulated reaction rates at the negative electrode/separator interface for the lithium intercalation and lithium deposition reactions as a function of charge time. The cell was charged galvanostatically at $2.906 \mathrm{~mA} / \mathrm{cm}^{2}$ ( $c a .1 C$ rate) to a cutoff voltage of $4.45 \mathrm{~V}$. The overpotential on the negative electrode is also shown as a function of charge time. The dashed line at $0.0 \mathrm{~V}(\mathrm{vs}$. $\mathrm{Li} / \mathrm{Li}^{+}$) shows the lithium deposition potential. It is clear from the figure that no lithium was deposited even when the cell was overcharged to $4.45 \mathrm{~V}$ because the cell had $19 \%$ excess negative electrode. The excess negative electrode makes the cell safer but compromises the performance of the cell. It also leads to larger irreversible capacity losses during the formation period.

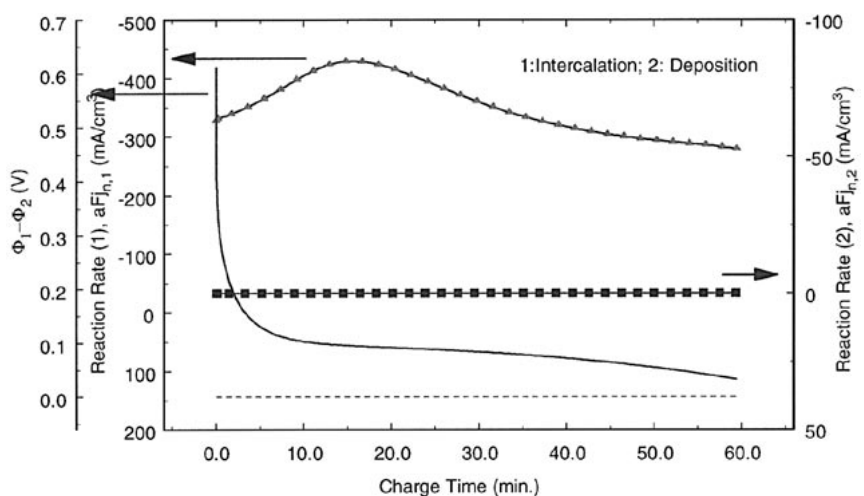

Figure 3. Simulated reaction rates as a function of charge time for $19 \%$ excess negative electrode (graphite). The cell is charged at $2.9 \mathrm{~mA} / \mathrm{cm}^{2}$ to $4.45 \mathrm{~V}$ and the results are shown at the negative electrode/separator interface.

The excess negative electrode active material used in commercial cells is often small to reduce the irreversible capacity loss to a minimum during the formation period. This improves the performance, but compromises the safety of these cells. Figure 4 shows the lithium deposition reaction as a function of charge time when the excess negative electrode is reduced to $5 \%$. As soon as the overpotential on the negative electrode reaches zero, the lithium deposition reaction becomes favorable. The rate of the lithium deposition reaction compared to that of lithium intercalation is very high at this location in the cell, and leads to a large amount of deposition within a short time. The cells with no excess negative electrode will be more prone to deposition compared to cells with excess negative electrode. Lithium deposition will also start earlier $(53 \mathrm{~min}$ for $0 \%$ excess anode, $57 \mathrm{~min}$ for $5 \%$ excess anode) in the absence of any excess negative electrode. The excess negative electrode clearly has a major effect on reducing the lithium deposition overcharge reaction.

Figure 5 shows the effect of charge cutoff voltage on the lithium deposition and intercalation rates. The cells were overcharged to three different cutoff voltages $(4.25,4.35$, and $4.45 \mathrm{~V})$ at $2.906 \mathrm{~mA} / \mathrm{cm}^{2}$ with $5 \%$ excess negative electrode. As expected, the lithium deposition reaction rate is higher when the cells are charged to higher cutoff voltages. The lithium deposition reaction dominates as soon as it begins, leading to an increase in the deposition rate and decrease in the intercalation rate. This problem becomes worse as the charging rate is increased. The value of the exchange current density for the lithium deposition/dissolution reaction as reported in the literature varies by two orders of magnitude. ${ }^{10,11}$ The large variation in values reported in the literature is likely due to the surface condition of the lithium under study. Freshly deposited lithium will have a high exchange current density compared to lithium covered with more-developed surface

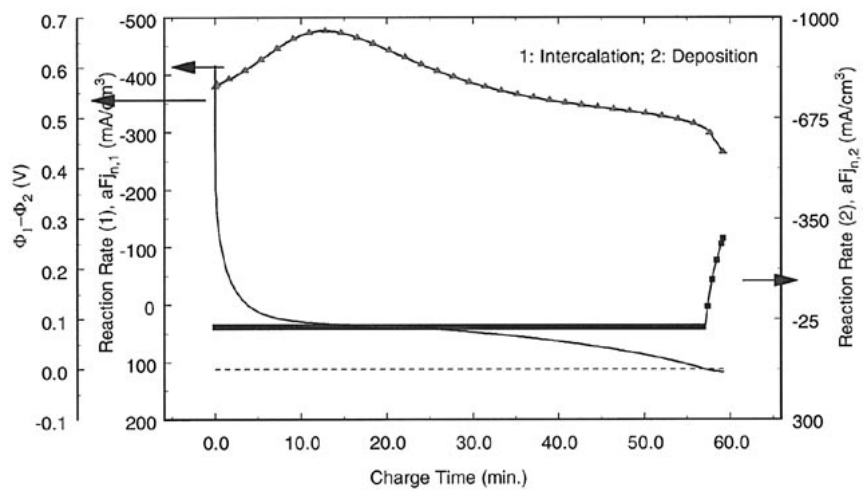

Figure 4. Simulated reaction rates as a function of charge time for 5\% excess negative electrode (graphite). The cell is charged at $2.9 \mathrm{~mA} / \mathrm{cm}^{2}$ to $4.45 \mathrm{~V}$ and the results are shown at the negative electrode/separator interface. 


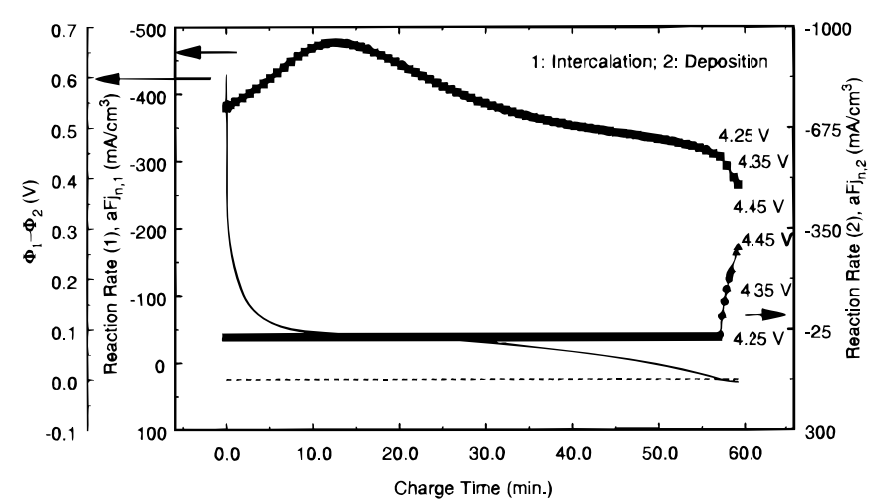

Figure 5. Simulated reaction rates as a function of charge time for different cutoff voltages $(4.25,4.35$, and $4.45 \mathrm{~V})$. The cell with $5 \%$ excess negative electrode is charged at $2.9 \mathrm{~mA} / \mathrm{cm}^{2}$ and the results are shown at the negative electrode (graphite)/separator interface.

films. Figure 6 shows the effect of exchange current density on the lithium deposition reaction $\left(0.1,1.0\right.$, and $\left.3.0 \mathrm{~mA} / \mathrm{cm}^{2}\right)$. At high exchange current densities, the rate of lithium deposition is very high and leads to a rapid depletion of lithium in the system.

Figures 3-6 model the lithium deposition reaction rate using a Butler-Volmer rate expression. If we assume that the lithium deposition reaction is irreversible and all the lithium deposited reacts with the electrolyte to form insoluble products, then a cathodic Tafel rate

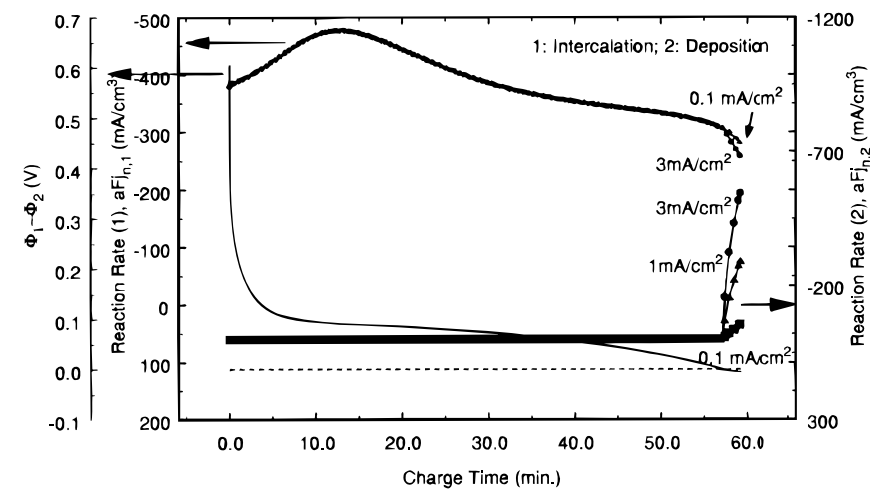

Figure 6. Simulated reaction rates as a function of charge time for different exchange current densities $\left(0.1,1.0\right.$, and $\left.3.0 \mathrm{~mA} / \mathrm{cm}^{2}\right)$ for the lithium deposition reaction. The cells with $5 \%$ excess negative electrode are charged at $2.9 \mathrm{~mA} / \mathrm{cm}^{2}$ to $4.45 \mathrm{~V}$ and the results are shown at the negative electrode (graphite)/separator interface.

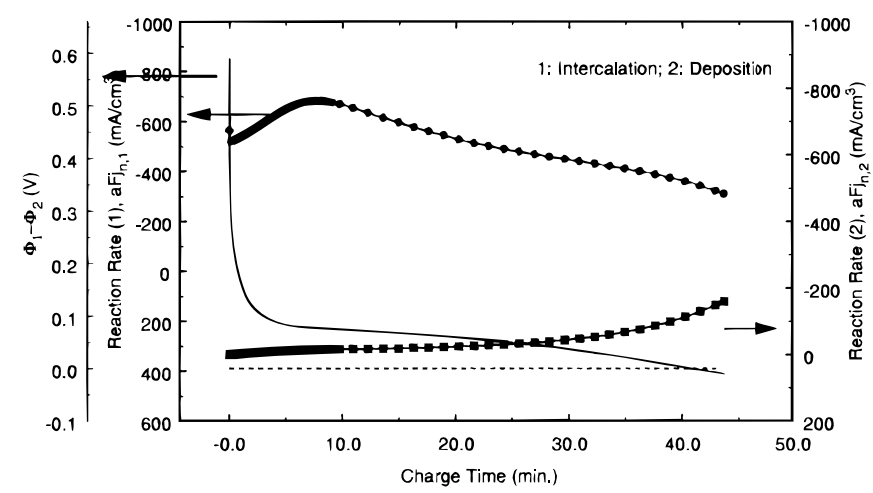

Figure 7. Simulated reaction rates as a function of charge time using a Tafel rate expression for the lithium deposition overcharge reaction. The cell with $5 \%$ excess negative electrode is charged at $2.9 \mathrm{~mA} / \mathrm{cm}^{2}$ to $4.45 \mathrm{~V}$ and the results are shown at the negative electrode (graphite)/separator interface.

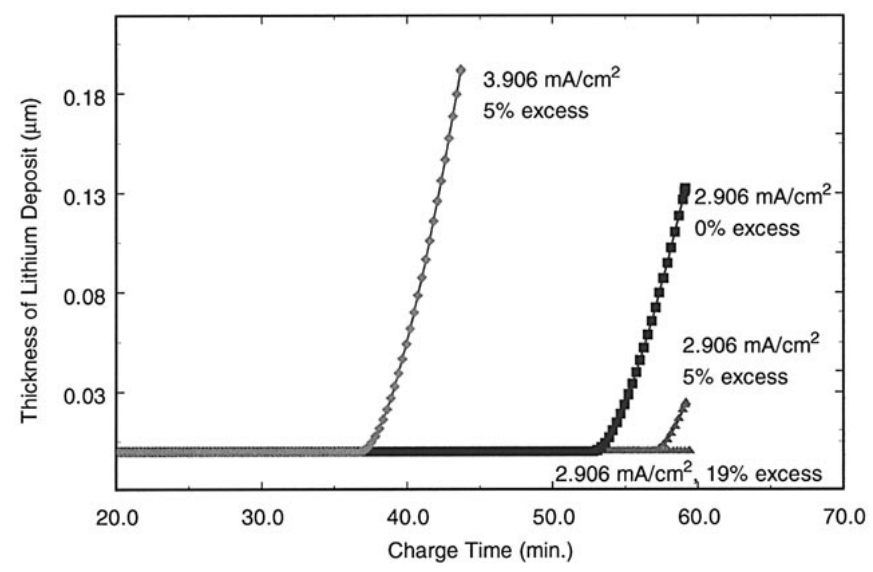

Figure 8. The predicted thickness of the lithium deposit under different operating conditions as a function of charge time. The cells with 5\% excess negative electrode are charged to $4.45 \mathrm{~V}$ and the results are shown at the negative electrode (graphite)/separator interface.

expression (Eq. 6) will suffice to describe the kinetics for the lithium deposition reaction. Figure 7 shows the lithium deposition reaction rate when a Tafel rate expression is used. In this case, the lithium deposition begins before the overpotential on the negative electrode reaches zero. The amount of lithium deposited in this case is larger compared to the Butler-Volmer rate expression under similar operating conditions.

As discussed above, a film is formed over the particles in the negative electrode during overcharge. This film consists of solid lithium and products formed by the reaction of lithium with electrolyte components. The thickness of this film under different operating conditions is shown in Fig. 8 assuming the film consists of solid metallic lithium only. As expected, a thicker film is formed when the cell is charged at higher rates. The film begins growing earlier when the excess capacity on the negative electrode is smaller.

Figure 9 summarizes the effect of different charging rates, charge cutoff voltages, and mass ratios on the amount of lithium deposited. The comparisons are shown for three different mass ratios $(0,5$, and $19 \%$ excess negative electrode), two different cutoff voltages (4.25 and $4.45 \mathrm{~V})$ and several different charging rates $\left(1.0-5.0 \mathrm{~mA} / \mathrm{cm}^{2}\right)$. In the case of cells with $19 \%$ excess negative electrode, lithium deposition will only occur when the cells are charged at rates greater than $3.9(4.45 \mathrm{~V})$ and $4.2 \mathrm{~mA} / \mathrm{cm}^{2}(4.25 \mathrm{~V})$ depending on the cutoff potential. Similarly, in the case of $5 \%$ excess negative electrode, the lithium deposition will begin at $2.5(4.45 \mathrm{~V})$ and $2.9 \mathrm{~mA} / \mathrm{cm}^{2}(4.25 \mathrm{~V})$

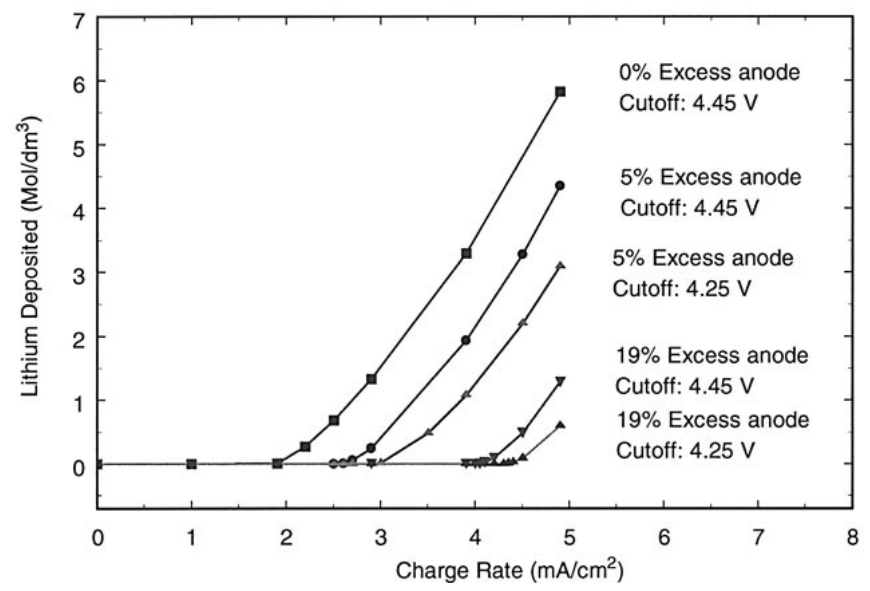

Figure 9. Amount of lithium deposited at the negative electrode/separator interface as a function of charge rate, mass ratio, and charge cutoff voltages for graphite negative electrodes. 
and in the case of $0 \%$ excess negative electrode, the lithium deposition will begin at $1.8(4.45 \mathrm{~V})$ and $2.25(4.25 \mathrm{~V}) \mathrm{mA} / \mathrm{cm}^{2}$. Thus in a cell with $5 \%$ excess negative electrode, lithium deposition will occur when it is charged to $4.25 \mathrm{~V}$ at the $1 C$ rate $\left(2.906 \mathrm{~mA} / \mathrm{cm}^{2}\right)$.

Active material particle size and negative electrode thickness play important roles in cell design. For these simulations, it is assumed that all of the particles are spherical and of equal size. Figure 10 compares the lithium deposition onset potential and amount of lithium deposited for three different grades of MCMBs (628, 1028 , and 2528 with average particle sizes of 6,10 , and $25 \mu \mathrm{m}$, respectively). The cells with 5\% excess anode were charged (and overcharged) at different rates $\left(2-8 \mathrm{~mA} / \mathrm{cm}^{2}\right)$ and to two different cutoff voltages $(4.25$ and $4.45 \mathrm{~V})$. It is clear from Fig. 10 that the cells with larger particles are more prone to lithium deposition compared to cells with smaller particles. This is because diffusion limitations lead to an increase in overpotential across the negative electrode in the cells with larger particles. Thus, for larger particles the overpotential on the negative electrode will reach zero earlier compared to smaller particles. However, smaller particles (larger surface area) lead to a larger irreversible capacity loss during the formation period. Thus optimization of particle size can be a subtle undertaking with several important considerations.

Figure 11 compares the amount of lithium deposited at the negative electrode/separator interface as a function of charge rate ( $C$ rate) for cells with different electrode thicknesses. The thicknesses of both electrodes were changed to keep the mass ratio constant (5\% excess negative electrode). The thicker electrodes are more prone to lithium deposition compared to thinner electrodes. Just as with the solid-phase diffusion limitations discussed above, solution-phase diffusion limitations become more prominent for thicker electrodes leading to more rapid lithium deposition. As shown in Fig. 11, the lithium deposition begins at $0.57 C$ for thicker electrodes (negative: $150 \mu \mathrm{m}$ and positive: $316 \mu \mathrm{m}$ ), at $0.90 C$ for medium electrodes (negative: $85 \mu \mathrm{m}$ and positive: $179 \mu \mathrm{m}$ ), and at $0.96 C$ for thin electrodes (negative: $70 \mu \mathrm{m}$ and positive: $148 \mu \mathrm{m}$ ), respectively when overcharged to $4.45 \mathrm{~V}$.

Low rates are typically used in constant-current charging so that lithium can intercalate uniformly throughout the electrode. The major disadvantages of constant-current charging are the longer time required and incomplete charging (nonuniform distribution of lithium). Constant-current charging followed by constant-voltage charging (taper charge) is a typical method of charging lithium-ion rechargeable batteries. In this method, constant-current charging is performed until the battery voltage reaches a preset value. After this voltage is reached, charging is switched to constant-voltage charging at the preset value. By increasing the charging current during the constant-current charging, the time needed to achieve full charge can be reduced. However, even though the constant-current charging

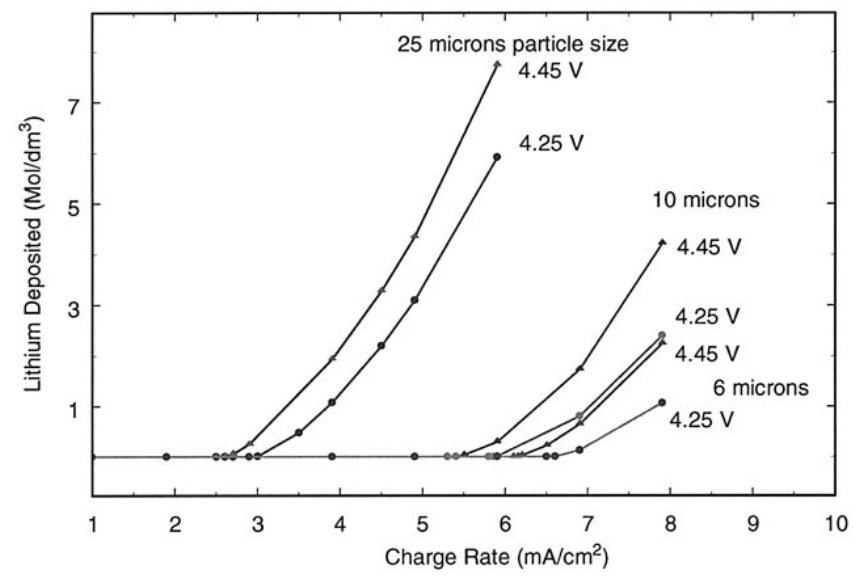

Figure 10. Amount of lithium deposited as a function of charge rate for different particle sizes (MCMB 628, 1028, and 2528) for graphite negative electrodes. The cells have $5 \%$ excess negative electrode and the results are shown at the negative electrode/separator interface.

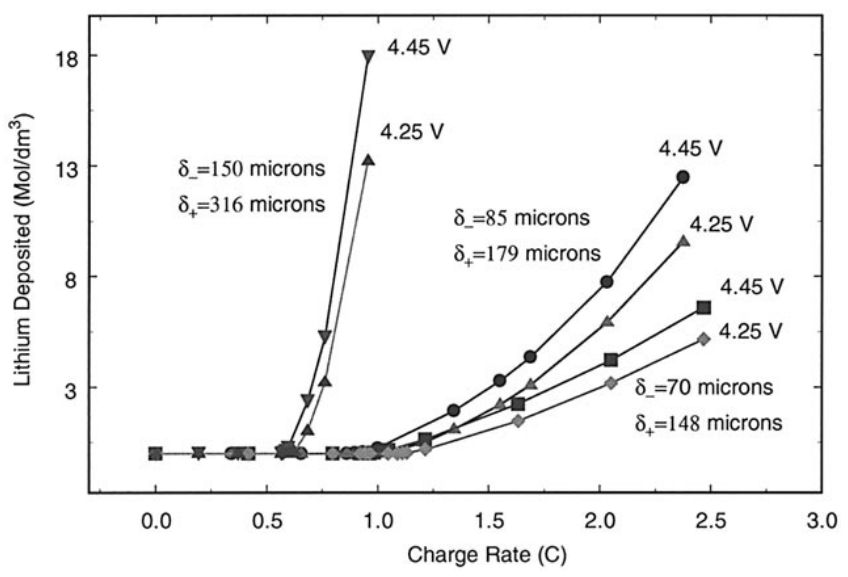

Figure 11. Amount of lithium deposited as a function of charge rate for different electrode thicknesses. The cells have $5 \%$ excess negative electrode and the results are shown at the negative electrode/separator interface. Both positive and negative electrode thicknesses were changed to maintain the mass ratio constant.

time is reduced by increasing the current, it does not follow that the more the charging current is increased, the more the charging time will be reduced. Further, when the charging current is increased above a certain level, degradation in battery performance becomes an issue. In this work, the two charging protocols (constant current and taper charge) will be compared to study their effects on the lithium deposition overcharge reaction.

During normal charging, all of the charge promotes lithium intercalation and none leads to deposition. During overcharge, lithium deposition occurs and a portion of the charge is consumed by the
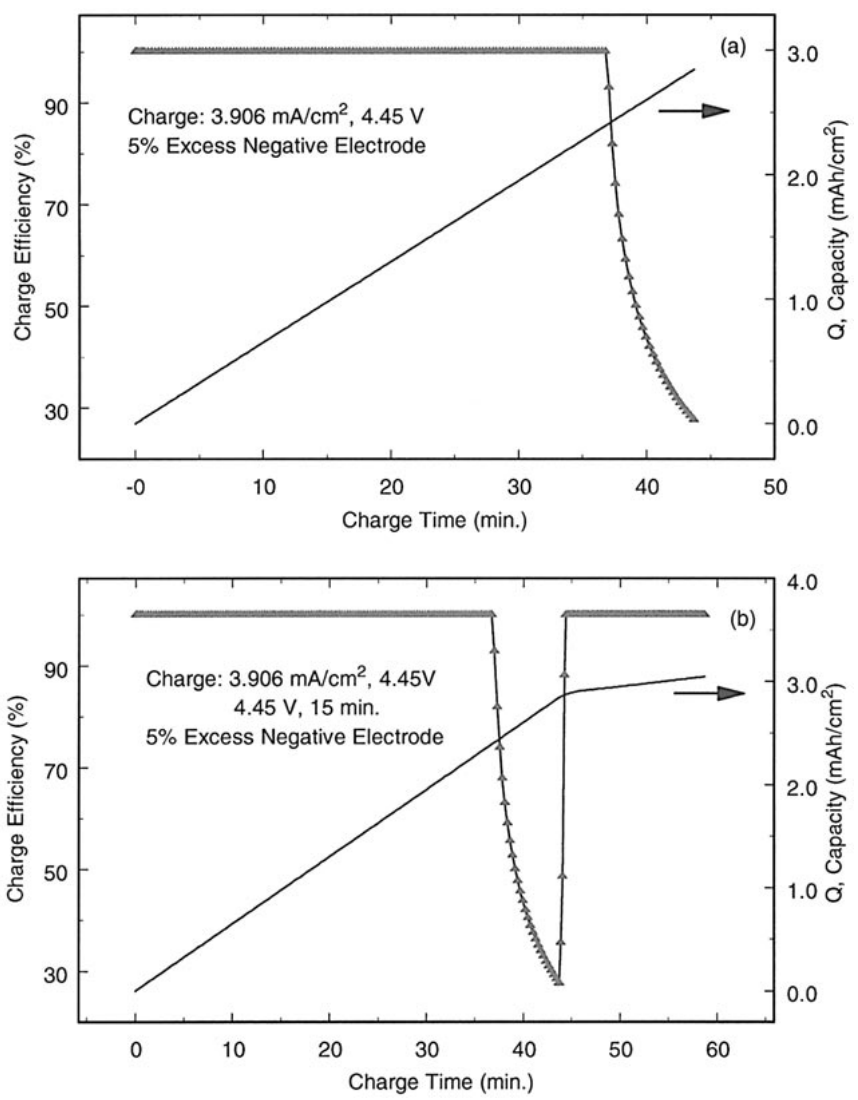

Figure 12. Charge efficiency at negative electrode (graphite)/separator interface as a function of charge time for (a) constant current and (b) taper charging. The capacity of the cell during charge is also shown. 
deposition reaction. Figures $12 \mathrm{a}$ and $\mathrm{b}$ present the charge efficiency as a function of charge time during constant-current and taper charge, respectively. The charge efficiency, in this case, is defined as

$$
\text { Charge efficiency }(\%)=\left(\frac{Q_{1}}{Q_{1}+Q_{2}}\right) 100 \%
$$

where $Q_{1}$ is the charge toward lithium intercalation and $Q_{2}$ is the charge toward the lithium deposition reaction at any point in the negative electrode. The charge efficiency, as defined, will vary across the negative electrode because in certain areas of the negative electrode no lithium deposition is occurring and all of the charge is going toward lithium intercalation. For constant-current charging (Fig. 12a), the charge efficiency remains high at nearly $100 \%$ during normal charging, but drops quickly when lithium deposition begins. During overcharge, the charge efficiency drops as more current promotes lithium deposition and less promotes lithium intercalation. During taper charging (Fig. 12b), the charge efficiency drops as soon as the lithium deposition begins but returns to $100 \%$ when the potentiostatic portion of the charge cycle begins. Only a very small quantity of lithium is deposited when the charging changes from constant current to constant potential. The capacity of the cell during constant-current charging and taper charging is also given in Fig. 12a and b.

Figures 13a and $b$ show the thickness and distribution of the solid lithium (deposit) film across the negative electrode at different charge times. Figure 13a shows simulation results for constant-current charging and Fig. 13b for taper charging. The cells (5\% excess negative electrode) were charged to $4.45 \mathrm{~V}$ at $3.906 \mathrm{~mA} / \mathrm{cm}^{2}$. A nonuniform current distribution in the negative electrode causes the front of the electrode to be filled with lithium earlier than the back, leading to a drop in overpotential at the front. It is clear from these
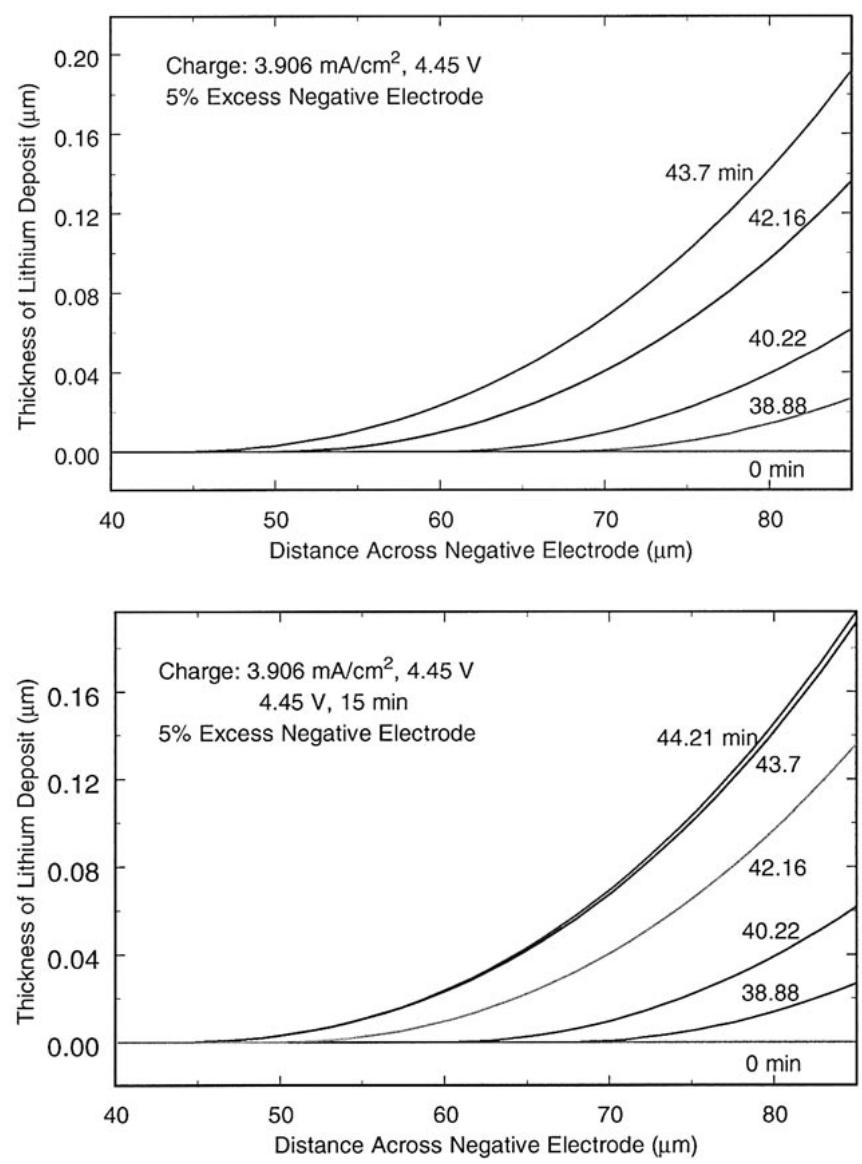

Figure 13. The predicted thickness of lithium deposit across the negative electrode (graphite) during (a) constant current and (b) taper charging at different charge times. graphs that the deposition begins first at the negative electrode/separator interface and then moves into the negative electrode. Lithium deposition was observed only in roughly a third of the negative electrode. During taper charging (Fig. 12b) lithium continues to deposit for a short time after the charging shifts from constant current to constant potential. This leads to a slightly larger lithium deposit in the negative electrode during taper charging as shown in Fig. 13b. The maximum film thicknesses observed for constant-current charge and taper charge were 0.1920 and $0.1993 \mu \mathrm{m}$, respectively, when charged at $3.906 \mathrm{~mA} / \mathrm{cm}^{2}$ to a cutoff potential of $4.45 \mathrm{~V}$.

During the formation period, a film (the SEI layer) is formed over the negative electrode, which leads to a large irreversible capacity loss during the first few cycles, but protects the negative electrode from further reaction with the electrolyte. The resistance of the SEI film is denoted by $R_{\mathrm{SEI}}$ as shown in Eq. 23. In the above simulations, $R_{\mathrm{SEI}}$ was considered to be negligible. In the past, many researchers have tried to determine the exact structure, composition, and thickness of the SEI film formed over either the lithium metal or lithiated carbon negative electrode. The thickness and resistance offered by the SEI layer as reported in the literature varies over two to three orders of magnitude as it depends on the specifics of the system under study. Figure 14 shows the effect of SEI layer resistance $\left(R_{\mathrm{SEI}}=50,200\right.$, and $\left.500 \Omega \mathrm{cm}^{2}\right)$ on the thickness of the film formed on the negative electrode during overcharge. The film formed over the negative electrode is thicker when the resistance offered by the SEI layer is lower and vice versa.

Figure 15 shows the resistance of the film formed during charge and overcharge for different film compositions (lithium and $\mathrm{Li}_{2} \mathrm{CO}_{3}$ ) when the cell with $5 \%$ excess negative electrode was overcharged at the $1 C\left(2.906 \mathrm{~mA} / \mathrm{cm}^{2}\right)$ rate to a cutoff voltage of $4.45 \mathrm{~V}$. The resistance of the film composed of lithium metal $\left(\kappa_{\mathrm{Li}} \sim 1.078 \times\right.$ $\left.10^{5} \mathrm{~S} / \mathrm{cm}\right)^{14}$ is negligible because of the high conductivity of lithium, whereas the films with different percentages of $\mathrm{Li}_{2} \mathrm{CO}_{3}\left(\kappa_{\mathrm{Li}_{2} \mathrm{CO}_{3}} \sim\right.$ $\left.1.2 \times 10^{-8} \mathrm{~S} / \mathrm{cm}\right)^{15,16}$ show an increase in resistance during overcharge. For example, an increase in resistance of about $50 \Omega \mathrm{cm}^{2}$ was observed at the negative electrode/separator interface at the end of charge when assuming that the film consists of $\mathrm{Li}_{2} \mathrm{CO}_{3}$ only. Because an increase in cell resistance is seen experimentally under overcharge conditions, this result supports the hypothesis that a fraction of the solid lithium reacts with the electrolyte to form $\mathrm{Li}_{2} \mathrm{CO}_{3}$ or other poorly conducting insoluble products. The fraction of lithium and $\mathrm{Li}_{2} \mathrm{CO}_{3}$ in the film might be determined by comparing the model predictions $\left(R_{\text {film }}\right)$ with experimental data upon extended cycling of these overcharged cells, although the complex nature of the film products will make these comparisons qualitative at best. Figure 16 shows the thickness of film formed over the graphite negative elec-

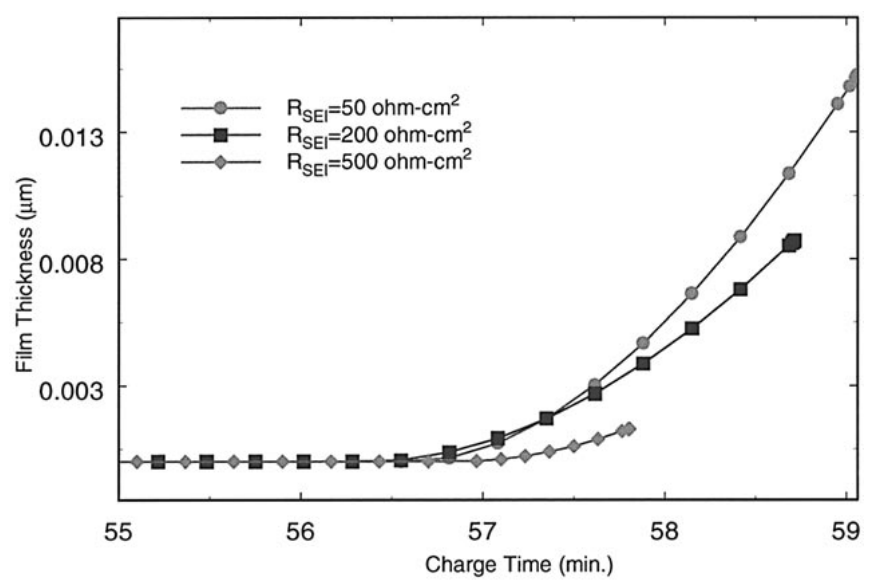

Figure 14. The predicted thickness of the film formed on the negative electrode (graphite) during overcharging in the presence of an SEI layer. The resistance of the SEI film was varied from 50 to $500 \Omega \mathrm{cm}^{2}$. The cells with $5 \%$ excess negative electrode are charged at $2.9 \mathrm{~mA} / \mathrm{cm}^{2}$ to $4.45 \mathrm{~V}$ and the results are shown at the negative electrode/separator interface. 


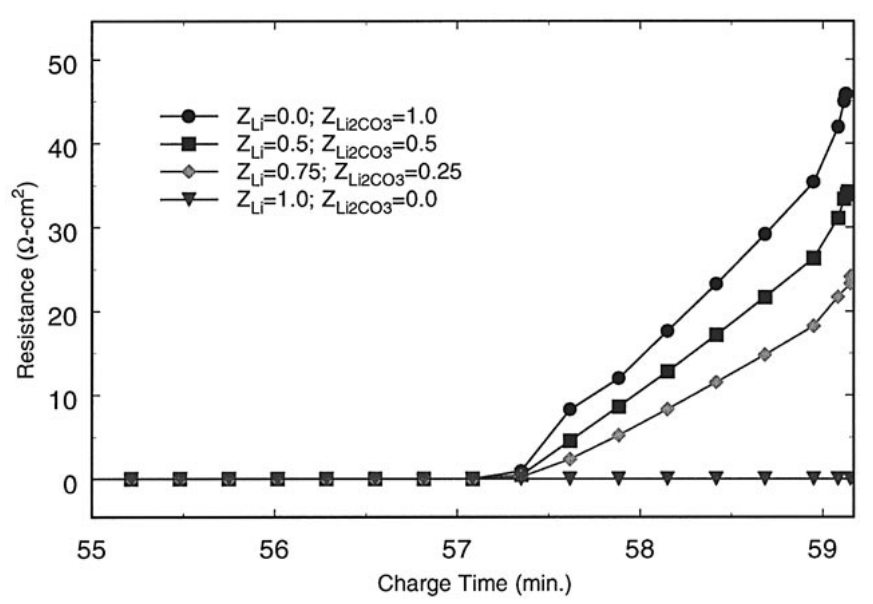

Figure 15. Resistance $\left(\Omega \mathrm{cm}^{2}\right)$ offered by the film formed during overcharging on the negative electrode (graphite) for different film compositions. The composition of the film was varied from pure metallic lithium to pure $\mathrm{Li}_{2} \mathrm{CO}_{3}$. The cells with $5 \%$ excess negative electrode are charged at $2.9 \mathrm{~mA} / \mathrm{cm}^{2}$ to $4.45 \mathrm{~V}$ and the results are shown at the negative electrode/separator interface.

trode for different compositions of the film. The thickness of the film is small when it is assumed that a portion of the lithium reacts with electrolyte to form insoluble highly resistive products. The higher resistance due to the passivation reactions increases the overvoltage as the film grows and eventually limits or terminates the lithium deposition side reaction. Thus, formation of a highly resistive film will limit the deposition of lithium on the negative electrode.

Coke vs. graphite.-Although amorphous carbons (coke) were first used by Sony in commercial lithium-ion batteries, graphite-based negative electrodes (e.g., MCMBs) have eclipsed the use of coke as active materials in most commercial batteries. Graphite is favored primarily due to its high lithium intercalation capacity (up to 372 $\mathrm{mAh} / \mathrm{g}$ ), and its low and flat lithium intercalation voltage curve. The low and flat lithium intercalation potential of the graphite $(\sim 100 \mathrm{mV}$ $\left.v s . \mathrm{Li} / \mathrm{Li}^{+}\right)$is a desirable factor for the maintenance of a flat cell voltage output. The reversible capacity of commercial coke materials (about 160-220 mAh/g, depending upon the specific coke material) are significantly lower than that of graphite. Furthermore, cokes have a sloping lithium insertion voltage between 0 and $1 \mathrm{~V} v s$. $\mathrm{Li}^{\prime} \mathrm{Li}^{+}$.

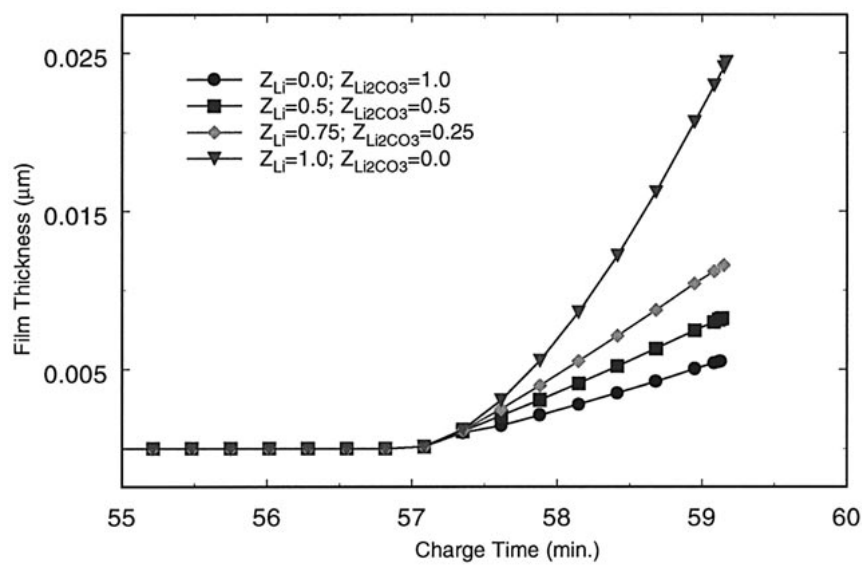

Figure 16. The predicted thickness of the film formed during overcharging on the negative electrode (graphite) for different film compositions. The composition of the film was varied from pure metallic lithium to pure $\mathrm{Li}_{2} \mathrm{CO}_{3}$. The cells with $5 \%$ excess negative electrode are charged at $2.9 \mathrm{~mA} / \mathrm{cm}^{2}$ to $4.45 \mathrm{~V}$ and the results are shown at the negative electrode/separator interface.
The electrode thicknesses and other parameters for coke electrodes were selected in such a way that charging conditions were similar to cells with graphite negative electrodes (discussed above). The theoretical mass ratio calculated on the basis of the theoretical capacity of the positive (148 $\mathrm{mAh} / \mathrm{g} \mathrm{m})$ and coke negative electrode $(372 \mathrm{mAh} / \mathrm{g} \mathrm{m})$ is 1.85 when using $\Delta y=0.83$ and $\Delta x=0.61 .{ }^{4}$ The actual mass ratio of cells (coke/ $\left./ \mathrm{LiMn}_{2} \mathrm{O}_{4}\right)$ with $19 \%$ excess negative electrode modeled in this study is 1.5 , with a $179 \mu \mathrm{m}$ thick negative electrode and a $179 \mu \mathrm{m}$ thick positive electrode. Upon changing, the thickness of the negative electrode to 145 and $153 \mu \mathrm{m}$, the excess capacity in the cell reduces to 0 and $5 \%$, respectively. The open-circuit potential $U_{1}$ for the coke electrode is a function of the amount of lithium inserted $(x=$ $\left.c_{\mathrm{s}} / c_{\mathrm{t}}\right)$ and can be described by Eq. $26^{3}$

$$
U_{1}=-0.160+1.32 \exp (-3.0 x)
$$

As discussed previously, lithium metal deposition may be more of a concern with graphitic carbon electrodes than with coke electrodes due to the lower average open-circuit potential of the former. Figure 17 shows the lithium intercalation and lithium deposition reaction rates when the cell with coke as the negative electrode was overcharged to $4.45 \mathrm{~V}$ at $2.856 \mathrm{~mA} / \mathrm{cm}^{2}$ ( $c a .1 C$ rate). As with the graphite electrode, the lithium intercalation rate begins decreasing as soon as the lithium deposition reaction begins. The lithium deposition reaction begins at $58.13 \mathrm{~min}$, which is longer than the time required for the lithium deposition reaction to begin on the graphite negative electrode (57.08 min) under similar conditions. As is clear from Fig. 17, the lithium intercalation rate is more uniform in the case of coke as compared to graphite. This is because the lithium insertion voltage in the coke material is more sloped than that for the graphite, which leads to a more uniform current distribution across the negative electrode. The sloping coke voltage is, therefore, more favorable for quick lithium insertion and deinsertion during highrate cell operation.

The flat and low average open-circuit potential of graphite electrodes makes them more prone to lithium deposition compared to the sloping open-circuit potential of coke electrodes. Figure 18 shows the thickness of the film formed over the negative electrode when the cell with $5 \%$ excess anode capacity was overcharged to $4.45 \mathrm{~V}$ at the $1 C$ and $1.35 C$ rates, respectively. The film thicknesses for both coke and graphite electrodes are shown in the figure. As expected, the lithium deposition reaction begins earlier on graphitic electrodes compared to coke electrodes. The film formed on coke electrodes was found to be $0.13 \mu \mathrm{m}$ thick (at the negative electrode/separator interface) whereas the film formed on the graphite electrode was $0.19 \mu \mathrm{m}$, assuming that the film consists of solid lithium only. Figure 19 shows the thickness of film formed over the coke negative electrode for different film compositions when the cell with $5 \%$ excess negative electrode was overcharged to $4.45 \mathrm{~V}$ at the $1.35 C$ charging rate. The film thickness for three different compositions (pure lithium, pure $\mathrm{Li}_{2} \mathrm{CO}_{3}$, and $50 \%$

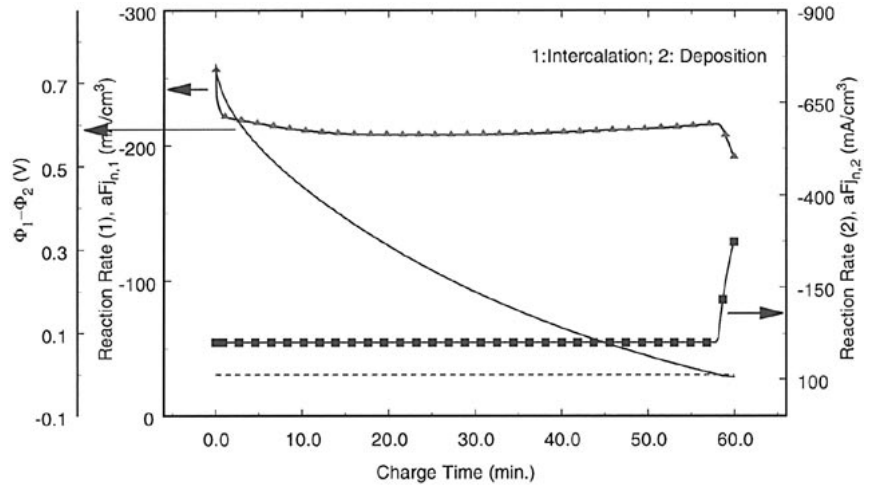

Figure 17 Simulated reaction rates as a function of charge time for 5\% excess negative electrode (coke). The cell is charged at $2.8 \mathrm{~mA} / \mathrm{cm}^{2}$ to $4.45 \mathrm{~V}$ and the results are shown at the negative electrode/separator interface. 


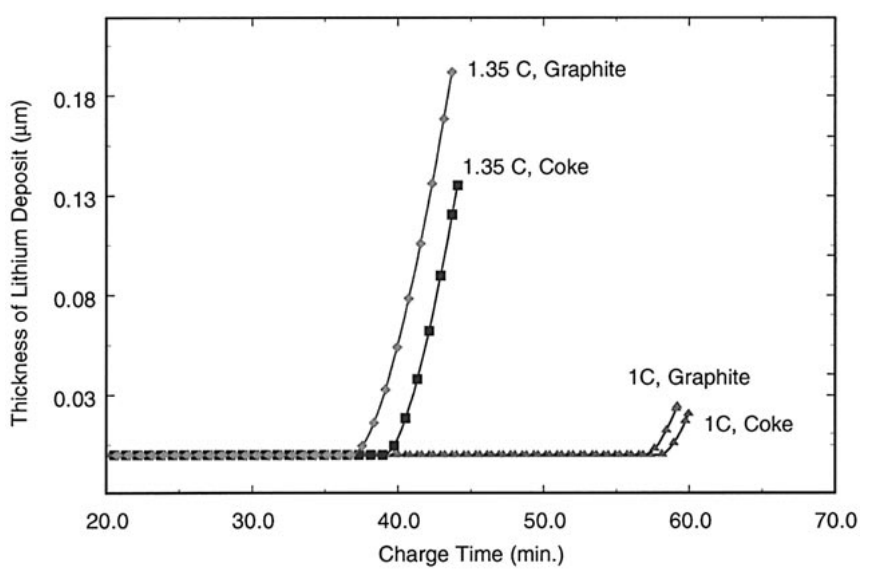

Figure 18. Comparison of film thicknesses formed during overcharging on coke and graphite-based negative electrodes. The cells with 5\% excess negative electrode are charged to $4.45 \mathrm{~V}$ and the results are shown at the negative electrode/separator interface.

lithium, $\left.50 \% \mathrm{Li}_{2} \mathrm{CO}_{3}\right)$ are shown in Fig. 19. A thick film $(0.14 \mu \mathrm{m})$ was observed when the film was assumed to consist of solid lithium only. When a part or all of the deposited lithium reacts with the electrolyte to form $\mathrm{Li}_{2} \mathrm{CO}_{3}$, the increase in resistance leads to a higher overpotential which ultimately either lowers the rate or terminates the lithium deposition reaction. The film thickness at the negative electrode/separator interface decreases to 0.03 and $0.01 \mu \mathrm{m}$ when it is assumed that the film consists of $50 \% \mathrm{Li}_{2} \mathrm{CO}_{3}$ and $100 \% \mathrm{Li}_{2} \mathrm{CO}_{3}$, respectively.

Cycling simulations.-To understand the effect of degradation mechanisms such as the lithium deposition overcharge reaction on long-term cycling of lithium-ion cells, it is very important to simulate the cycling behavior of lithium-ion cells. The comparison between cycling simulations and experimental data should improve the predictive capability of the model. As discussed in previous sections, overcharging of lithium-ion cells leads to lithium deposition on the negative electrode, which ultimately results in increased cell resistance and capacity loss. In this section, the cycling behavior of lithium-ion cells will be simulated to predict the capacity loss when cells are overcharged under various durations and severities. These cycling simulations will help to predict the capacity loss due to the lithium deposition overcharge reaction and will aid in determining the reasons behind the capacity loss observed after an overcharge event.

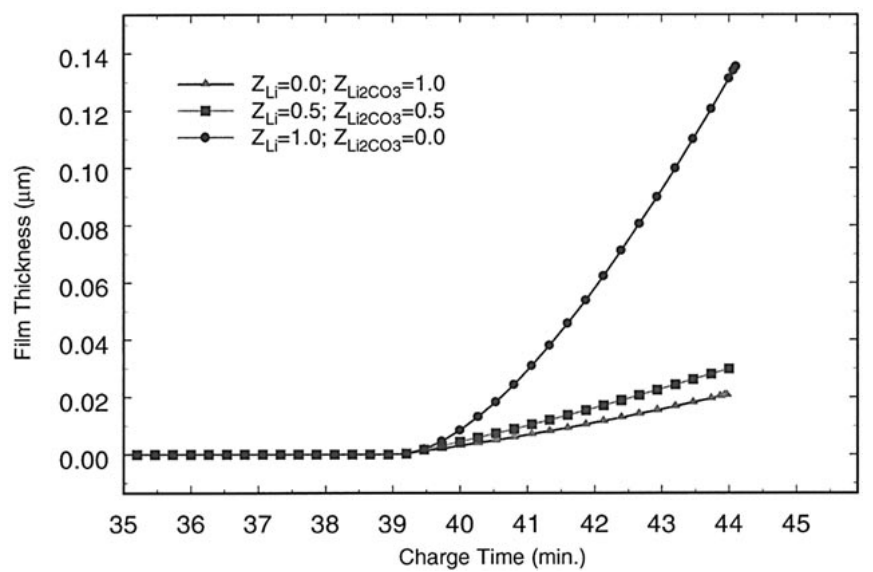

Figure 19. The predicted thickness of the film formed during overcharging on coke-based negative electrodes for different film compositions. The composition of the film was varied from pure metallic lithium to pure $\mathrm{Li}_{2} \mathrm{CO}_{3}$. The cells with $5 \%$ excess negative electrode are charged at $3.8 \mathrm{~mA} / \mathrm{cm}^{2}$ to $4.45 \mathrm{~V}$ and the results are shown at the negative electrode/separator interface.
Overcharging of lithium-ion cells can occur due to poor cell design, adverse charging conditions, or accidental overcharging due to charger malfunction. Two common cases are used to study the effect of the overcharge reaction on the cycling behavior of these cells. The first case is accidental overcharge to a higher voltage than the prescribed cutoff voltage and the second case is of continued overcharging or abuse due to malfunction of the charger. The first case represents a single accidental overcharge incident as shown in Fig. 20 and 21, the first being less severe than the second. Both figures show capacity loss, film thickness, and film resistance as a function of cycle number. In both cases, cells with $5 \%$ excess negative electrode capacity were overcharged at the $1 C$ rate during the 5 th cycle. In Fig. 20, the cell was overcharged to $4.3 \mathrm{~V}$ whereas in Fig. 21, the cell was overcharged to $4.5 \mathrm{~V}$, respectively. In all other cycles, the cells were charged at the $1 C$ rate to $4.2 \mathrm{~V}$ and discharged at the $1 C$ rate to $3.0 \mathrm{~V}$ with a $5 \mathrm{~min}$ rest period between each step.

The capacity loss observed was very small when the cell was overcharged to $4.3 \mathrm{~V}$, compared to $0.25 \%$ capacity loss when the cell was overcharged to $4.5 \mathrm{~V}$ (Fig. 21). The capacity loss per cycle is defined as

Capacity loss $(\%)=\frac{Q(\text { before overcharge })-\mathrm{Q}(\text { after overcharge })}{Q(\text { before overcharge })}$

In these simulations, it was assumed that the film formed on the negative electrode consists of $50 \%$ metallic lithium and $50 \% \mathrm{Li}_{2} \mathrm{CO}_{3}$. The capacity loss observed after overcharge can be due to the in-

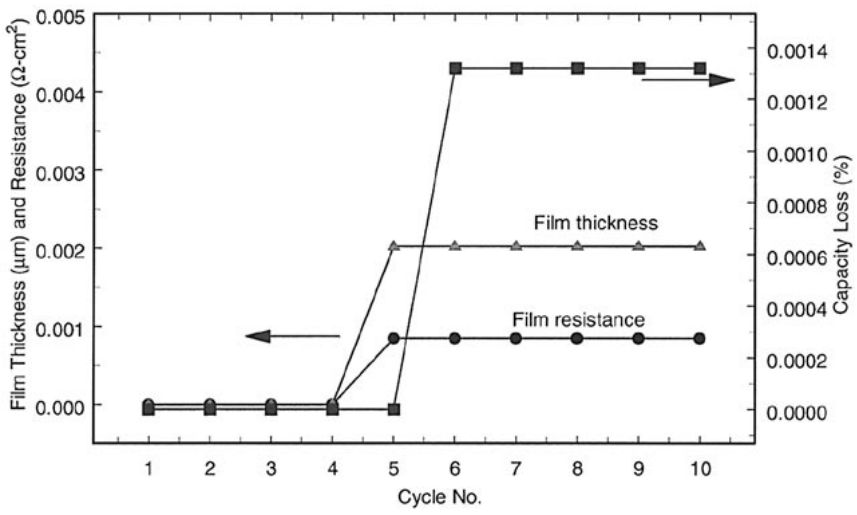

Figure 20. Capacity loss $(\%)$, film thickness $(\mu \mathrm{m})$, and film resistance $\left(\Omega \mathrm{cm}^{2}\right)$ as a function of cycle number. The cell was overcharged to $4.3 \mathrm{~V}$ at the $1 C$ rate during the 5 th cycle. The film formed on the negative electrode was assumed to consist of $50 \%$ metallic lithium and $50 \% \mathrm{Li}_{2} \mathrm{CO}_{3}$.

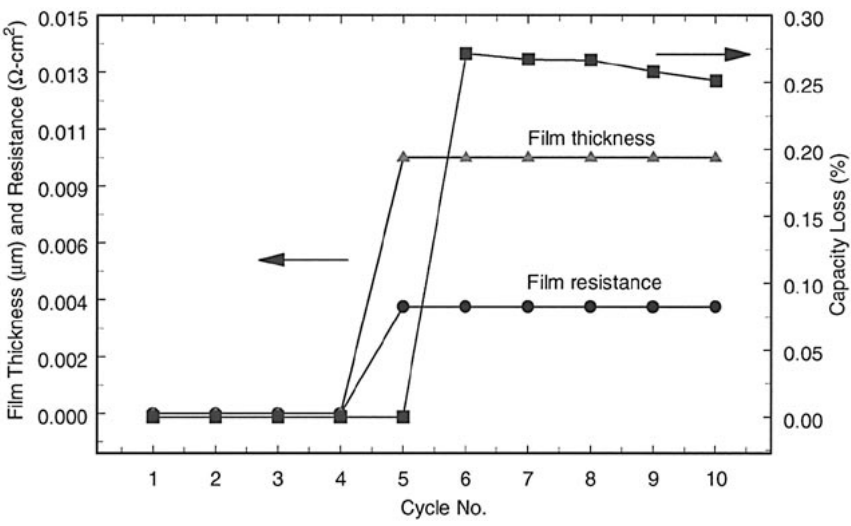

Figure 21. Capacity loss $(\%)$, film thickness $(\mu \mathrm{m})$, and film resistance $\left(\Omega \mathrm{cm}^{2}\right)$ as a function of cycle number. The cell was overcharged to $4.5 \mathrm{~V}$ at the $1 C$ rate during the 5th cycle. The film formed on the negative electrode was assumed to consist of $50 \%$ metallic lithium and $50 \% \mathrm{Li}_{2} \mathrm{CO}_{3}$. 
crease in cell resistance due to the film formed and the inherent capacity loss due to overcharge itself (which is a constant value and does not change after the overcharge is completed). In Fig. 20 and 21 , the capacity loss is observed only during the overcharge cycle. The capacity loss remains nearly constant in later cycles due to the absence of other degradation mechanisms in the model. This suggests that if experimental data show a further loss of capacity after overcharge, it must be due to additional mechanisms that are not considered in this model. In Fig. 21, the capacity loss appears to decrease slightly after normal charging is resumed. This recovery of capacity loss is larger for cells overcharged to $4.5 \mathrm{~V}$ compared to cells overcharged to $4.3 \mathrm{~V}$. After a few cycles, the capacity loss tends to remain constant.

In the second case, single cells are overcharged for multiple cycles as if there was a weak cell in a cell stack which continued to be overcharged. Figure 22 shows the capacity loss $(\%)$, film thickness $(\mu \mathrm{m})$, and film resistance $\left(\Omega \mathrm{cm}^{2}\right)$ as a function of cycle number when the cell was overcharged to $4.5 \mathrm{~V}$ at the $1 C$ rate for 6 cycles (cycles no. 5-10). The capacity of the cell decreases during overcharging and the film thickness and resistance increase with each overcharge period. The increase in resistance during overcharge limits the growth of the film during later overcharge cycles. As discussed in the first case, it was assumed that the film formed consisted of $50 \%$ metallic lithium and $50 \% \mathrm{Li}_{2} \mathrm{CO}_{3}$. It is clear from Fig. 22 that the loss of capacity during multiple overcharge cycles decreases with each overcharge. This diminishing capacity effect is due to the increase in the cell resistance, which limits the lithium deposition reaction even though the cell is overcharged to the same cutoff voltage $(4.5 \mathrm{~V})$.

The capacity loss observed after an overcharge period can be purely due to lost capacity (from the deposited/reacted lithium) or due to an increase in resistance/loss of rate capability. To determine the exact reason for capacity fade, another simulation was carried out assuming that all of the lithium deposited remains as metallic lithium (leading to negligible film resistance). Figure 23 shows the capacity loss for two different film compositions: one with metallic lithium only and the other with $50 \%$ lithium and $50 \% \mathrm{Li}_{2} \mathrm{CO}_{3}$. The capacity loss observed was higher when the film composition was assumed to be $50 \%$ lithium and $50 \% \mathrm{Li}_{2} \mathrm{CO}_{3}$. In the other case, when it was assumed that the film deposited consisted of solid lithium only, there was no increase in resistance during overcharge and thus capacity loss was due to the lithium lost only during overcharge. Figure 23 also shows the capacity loss observed in the cell when it is not overcharged, as a reference.

The cycling simulation results show clearly that the capacity loss due to overcharge occurs only in the cycle(s) during which the cell is overcharged. In experimental cells, it may be the case that capacity decay is also observed in the cycles following the overcharge cycle. This is likely due to the other degradation mechanisms (such

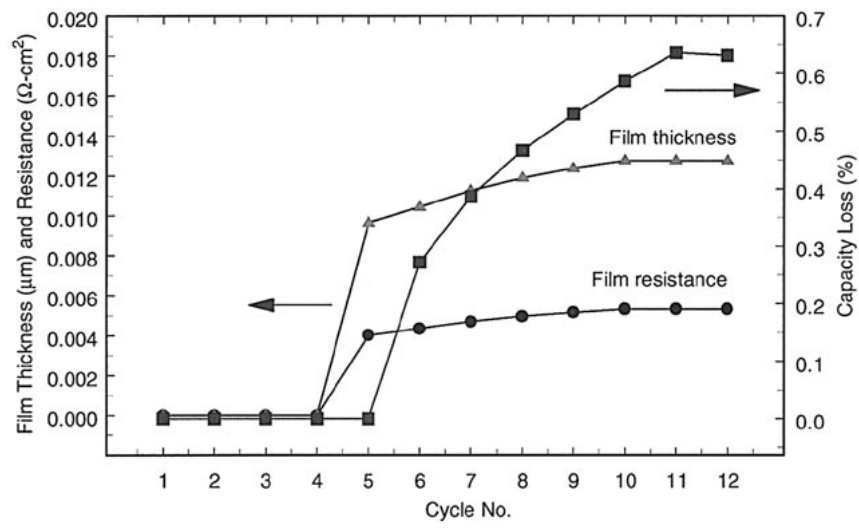

Figure 22. Capacity loss $(\%)$, film thickness $(\mu \mathrm{m})$, and film resistance $\left(\Omega \mathrm{cm}^{2}\right)$ as a function of cycle number. The cell was overcharged to $4.5 \mathrm{~V}$ at the $1 C$ rate during cycles 5-10. The film formed on the negative electrode was assumed to consist of $50 \%$ metallic lithium and $50 \% \mathrm{Li}_{2} \mathrm{CO}_{3}$.

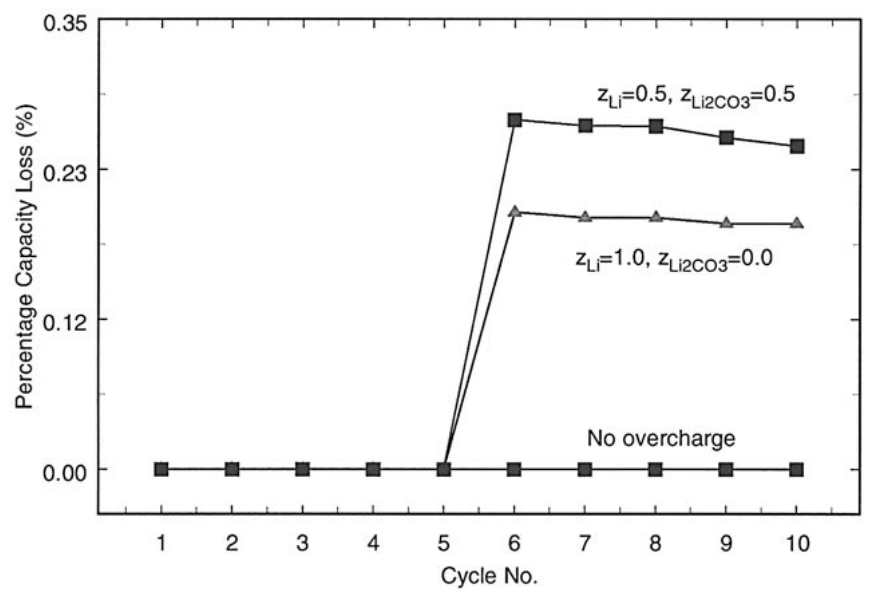

Figure 23. Capacity loss (\%) as a function of cycle number for different film compositions. The cells were overcharged to $4.5 \mathrm{~V}$ at the $1 C$ rate during the 5 th cycle. The capacity loss during normal cycling without any overcharge is also shown for reference.

as the production of soluble electrochemically active solvent oxidation-reduction products) which are presently not included in the mathematical model. The comparison of these simulations with experimental data can be used to improve the model in the future.

This work provided preliminary simulation results to predict the conditions that lead to the lithium deposition side reaction during overcharging of lithium-ion cells. Many other important features must be incorporated into the model to provide a better understanding of the lithium deposition overcharge reaction. Future improvements and complications that could be added to the lithium deposition overcharge reaction are secondary reactions of solid lithium to form more SEI film products and growth of the film to the stage wherein the porosity of the electrode changes to a significant extent.

\section{Conclusions}

The mathematical model presented here is used to predict the onset of lithium metal deposition in lithium-ion cells during charge and overcharge. The lithium deposition side reaction affects the efficiency of the charging and discharging processes. The amount of lithium deposited varied from $0-3.0 \mathrm{M} / \mathrm{dm}^{3}$ (1.0-1.35 $C$ charging rate, $5 \%$ excess capacity) and the thickness of these films varied from 0 to $0.2 \mu \mathrm{m}$ under various simulation conditions. Although specific positive and negative electrode materials were used in the simulations, the conclusions are expected to be general.

Model predictions can be used to establish operational and design limits within which the lithium deposition overcharge reaction can be avoided. For example, a cell with 5\% excess negative electrode when charged to $4.25 \mathrm{~V}$ at the $1 C$ rate $\left(2.906 \mathrm{~mA} / \mathrm{cm}^{2}\right)$ will lead to lithium deposition. No lithium deposition will be observed until $4.2 \mathrm{~V}$. If the same cell had $19 \%$ excess negative electrode, no lithium deposition would be observed even if the cell was overcharged to $4.45 \mathrm{~V}$ at the $1 C$ rate. But at higher rates $(>1.5 C)$, a small amount of lithium deposition will be observed when the cell is overcharged to $4.45 \mathrm{~V}$. Thus the excess negative electrode will reduce the risk of lithium deposition but will lead to more irreversible capacity loss during the formation period and lower capacity (e.g., $372 \mathrm{mAh} / \mathrm{g} \times(1-0.19)$ about $300 \mathrm{mAh} / \mathrm{g}$ reversible capacity for $19 \%$ excess anode) in the negative electrode.

These losses in capacity (due to the excess anode and the formation period) make noncarbon and metallic anodes (tin-based anodes, etc.) more attractive because their open-circuit potential is not low enough for lithium deposition to be a concern. Active material particle size and electrode thickness also affect the onset of the lithium deposition overcharge reaction. Thinner electrodes with smaller particle size are less prone to the lithium deposition overcharge reaction than thicker electrodes with larger particles due to overpotential considerations. 
The lithium distribution across the negative electrode was predicted under different charging conditions. Lithium deposition begins first at the negative electrode/separator interface and then moves into the negative electrode. The film formed by the lithium deposit is slightly thicker in the case of taper charging (maximum thickness $=0.199 \mu \mathrm{m}$ ) than in constant current-charging (maximum thickness $=0.192 \mu \mathrm{m}$ ). The increase in cell resistance during overcharge supports the hypothesis that a fraction of the solid lithium reacts with the electrolyte to form $\mathrm{Li}_{2} \mathrm{CO}_{3}$ or other poorly conducting insoluble products. When overcharged under similar conditions, lithium deposition begins earlier in cells with graphite negative electrodes compared to cells with coke negative electrodes. The cycling behavior of lithium-ion cells was simulated to predict the capacity loss when cells are overcharged under various conditions.

\section{Acknowledgments}

P.A. and R.E.W. acknowledge the financial support from the Office of Research and Development of the United States Central Intelligence Agency for this project under contract no. 93-F148100-100.

The University of South Carolina assisted in meeting the publication costs of this paper.

\section{List of Symbols}

a specific interfacial area per unit volume of negative electrode, $\mathrm{cm}^{-1}$

$c_{\mathrm{i}} \quad$ concentration of species $\mathrm{i}, \mathrm{mol} / \mathrm{cm}^{3}$

$c_{\mathrm{s}} \quad$ concentration of lithium in solid phase, $\mathrm{mol} / \mathrm{dm}^{3}$

$c_{\mathrm{t}} \quad$ maximum concentration in intercalation material, $\mathrm{mol} / \mathrm{dm}^{3}$

$C \quad$ rate at which cell discharge in $1 \mathrm{~h}$; theoretical coulombic capacity of insertion material based on discharged state, $\mathrm{mAh} / \mathrm{g}$

$D_{\mathrm{s}} \quad$ diffusion coefficient of lithium in the solid electrode, $\mathrm{cm}^{2} / \mathrm{s}$

F Faraday's constant, $96487 \mathrm{Cleq}$

$i \quad$ current density, $\mathrm{A} / \mathrm{cm}^{2}$

$i_{\mathrm{o}, \mathrm{k}} \quad$ exchange current density of reaction $\mathrm{k}, \mathrm{A} / \mathrm{cm}^{2}$

$j_{\mathrm{n}, \mathrm{k}} \quad$ pore wall flux across interface, $\mathrm{mol} / \mathrm{cm}^{2} \mathrm{~s}$

$k$ reaction rate constant

$m$ mass of active material in composite electrode, $\mathrm{g} / \mathrm{cm}^{2}$

M molecular weight, $\mathrm{g} / \mathrm{mol}$

$n$ number of electrons transferred in electrochemical reactions

$N_{\mathrm{i}} \quad$ molar flux of species i, $\mathrm{mol} / \mathrm{cm}^{2} \mathrm{~s}$

$Q \quad$ capacity, $\mathrm{mAh} / \mathrm{cm}^{2}$

$R \quad$ ideal gas constant, $8.314 \mathrm{~J} / \mathrm{mol} \mathrm{K}$

$R_{\mathrm{i}} \quad$ rate of generation of species $\mathrm{i}, \mathrm{mol} / \mathrm{cm}^{3} \mathrm{~s}$

$R_{\text {film }}$ film resistance, $\Omega \mathrm{cm}^{2}$

$R_{\mathrm{S}} \quad$ radius of solid particles, $\mathrm{m}$

$R_{\mathrm{SEI}} \quad$ resistance of SEI film, $\Omega \mathrm{cm}^{2}$

$s_{\mathrm{i}} \quad$ stoichiometric coefficient of species i

time, s

temperature, ${ }^{\circ} \mathrm{C}$

open-circuit potential, $\mathrm{V}$

stoichiometric coefficient for carbon electrode, $\mathrm{Li}_{x} \mathrm{C}_{6}$

stoichiometric coefficient for manganese oxide electrode, $\mathrm{Li}_{y} \mathrm{Mn}_{2} \mathrm{O}_{4}$
Greek

$\alpha \quad$ transfer coefficient

$\gamma \quad$ mass ratio of positive to negative active material

$\delta \quad$ thickness, cm

$\sigma \quad$ electronic conductivity of solid matrix, $\mathrm{S} / \mathrm{cm}$

$\epsilon_{i} \quad$ volume fraction of component $i$

$\eta \quad$ surface overpotential, V

ionic or electronic conductivity, $\mathrm{S} / \mathrm{cm}$

density of material, $\mathrm{g} / \mathrm{cm}^{3}$

$\phi \quad$ electrical potential, $\mathrm{V}$

Subscripts

$+\quad$ positive electrode

- negative electrode

a anode

c cathode

cc current collector

f conductive filler

$\mathrm{k}$ reaction number

1 liquid phase of plasticized electrolyte

$\mathrm{p} \quad$ polymer phase of plasticized electrolyte

s separator

1 solid matrix

2 solution phase

Superscripts

$0 \quad$ with respect to solvent or initial condition

\section{References}

1. P. Arora, R. E. White, and M. Doyle, J. Electrochem. Soc., 145, 3647 (1998).

2. M. Doyle, T. F. Fuller, and J. Newman, J. Electrochem. Soc., 140, 1527 (1993).

3. T. F. Fuller, M. Doyle, and J. Newman, J. Electrochem. Soc., 141, 1 (1994).

4. M. Doyle, J. Newman, A. S. Gozdz, C. N. Schmutz, and J. M. Tarascon, J. Electrochem. Soc., 143, 1890 (1996).

5. P. Arora, M. Doyle, A. S. Gozdz, R. E. White, and J. Newman, Advances in Mathematical Modeling and Simulation of Electrochemical Processes and Oxygen Depolarized Cathodes for Chlor-Alkali and Chlorate Processes, J. W. Van Zee, T. F. Fuller, P. C. Foller, and F. Hine, Editors, PV 98-10, p. 29, The Electrochemical Society Proceedings Series, Pennington, NJ (1998).

6. R. Darling and J. Newman, J. Electrochem. Soc., 145, 990 (1998).

7. A. N. Dey and B. P. Sullivan, J. Electrochem. Soc., 117, 222 (1970).

8. R. Fong, U. Von Sacken, and J. R. Dahn, J. Electrochem. Soc., 137, 2009 (1990).

9. J. S. Newman, Electrochemical Systems, 2nd ed., Prentice Hall, Englewood Cliffs, NJ (1991).

10. R. Jasinski, Advances in Electrochemistry and Electrochemical Engineering, Vol. 8, P. Delahay and C. W. Tobias, Editors, Wiley-Interscience, New York (1971)

11. M. W. Verbrugge and B. J. Koch, J. Electroanal. Chem., 367, 123 (1994).

12. M. W. Verbrugge, AIChE J., 41, 1550 (1995).

13. E. Peled, D. Golodnitsky, C. Menachem, and D. Bar-Tow, J. Electrochem. Soc., 145, 3482 (1998).

14. D. D. Hsu, Chemical periodic table, J. Chemical Education Online, http://wwwtech.mit.edu/Chemicool/elements/lithium.html.

15. Y. Geronov, F. Schwager, and R. H. Muller, in Lithium Nonaqueous Battery Electrochemistry, E. G. Yeager, B. Schumm, G. Blomgren, D. R. Blankenship, V. Leger, and J. Akridge, Editors, PV 80-7, p. 115, The Electrochemical Society Proceedings Series, Princeton, NJ (1980).

16. E. Peled, Ambient Temperature Lithium Batteries, J. P. Gabano, Editor, Academic Press, New York (1983). 